Trinity College

Trinity College Digital Repository

Faculty Scholarship

Fall 2020

Sarti's Fra i due litiganti and Opera in Vienna

John Platoff

Trinity College, john.platoff@trincoll.edu

Follow this and additional works at: https://digitalrepository.trincoll.edu/facpub

Part of the Musicology Commons 


\section{Sarti's Fra $i$ due litiganti and Opera in Vienna}

\section{JOHN PLATOFF}

$\mathrm{I}$ n June 1784, Giuseppe Sarti passed through Vienna on his way from Milan to St. Petersburg, where he would succeed Giovanni Paisiello as director of the imperial chapel for Catherine the Great. On June 2, he attended a performance at the Burgtheater of his opera buffa Fra $i$ due litiganti il terzo gode, which was well on its way to becoming one of the most successful operas of the late eighteenth century. At the order of Emperor Joseph II, Sarti was given the proceeds of the evening's performance, which amounted to the substantial sum of 490 florins. ${ }^{1}$

Premiered at La Scala in Milan on September 14, 1782, Fra $i$ due litiganti had almost immediately begun to receive productions in other cities. It was performed in Venice under the title I pretendenti delusi; and it was the third opera produced in Vienna by the newly reestablished opera buffa company there in the spring of 1783. By the time of Sarti's visit to the Habsburg capital a year later, Fra $i$ due litiganti was the most popular opera in Vienna. It had already been performed twenty-eight times in its first season alone, a total unmatched by any other operatic work of the decade. Thus the emperor's gift to Sarti was an understandable acknowledgment of his opera's success. ${ }^{2}$

By no means, however, did the performance on June 2 present the opera as Sarti had written it for its premiere in Milan twenty-one months earlier. No fewer than six of the fifteen arias performed were pieces newly substituted in Vienna, by composers including Pasquale Anfossi, Vicente Martín y Soler, and Antonio Salieri. We may assume that being applauded and honored for a work that was not entirely his did not disturb Sarti in the least. It is well known that as operas traveled to different cities, numbers were frequently replaced to suit the needs of singers.

What is surprising, though, is that the "Viennese version" of Fra $i$ due litiganti that Sarti heard-with substitute pieces by other composerswas already on its way to becoming the standard version, at least in most cities north of the Alps. As the opera triumphed in one opera house after another, receiving well over one hundred productions by 1800, it was frequently presented not in the original version by Sarti but as altered in Vienna.

1. See Link, National Court Theatre, 42 and $n 35$.

2. In an era before the advent of international copyright laws, composers received no compensation when their operas were performed in other cities. Sarti's only income from Fra $i$ due litiganti would have been a onetime payment for the work from La Scala in Milan.

Journal of the American Musicological Society, Vol. 73, Number 3, pp. 535-581 ISSN 0003-0139, electronic ISSN 1547-3848. @ 2020 by the American Musicological Society. All rights reserved. Please direct all requests for permission to photocopy or reproduce article content through the University of California Press's Reprints and Permissions web page, http://www.ucpress.edu/journals.php?p=reprints. DOI: https://doi.org/10.1525/jams.2020.73.3.535. 
The Viennese version flourished in at least two different German translations, and it was the basis for a French version in four acts that audiences enjoyed in Paris, Brussels, and elsewhere in French-speaking Europe.

The numerous surviving sources for Fra $i$ due litiganti reveal two very different patterns of transmission. In many theaters, especially in Italy, the pattern more familiar to opera scholars prevailed: the work was presented in a version close to Sarti's Milanese original, with the substitution of a few arias here and there, presumably to accommodate the local singers. But in much of the rest of Europe, the Viennese version was performed with remarkably few changes, no doubt reflecting the dominance of Vienna as the most important center for Italian opera in the German-speaking world. Moreover, the surviving manuscript scores demonstrate the centrality of the Viennese theater's music copying firm, led by Wenzel Sukowaty, as a source for operatic manuscripts purchased by opera houses from Eszterháza to Paris and from Bolzano to Copenhagen.

Sarti's opera played a central role in the operatic life of Vienna, with connections to Mozart and Da Ponte's Le nozze di Figaro and to the careers of the singers Nancy Storace and Francesco Benucci. These two, the leading performers of Vienna's opera buffa company, created the roles of Susanna and Figaro in Mozart's opera. They also sang leading roles in Fra $i$ due litiganti-both in Vienna and in the original production in Milan. And the changes made for the two singers in the Viennese version-as opposed to what they performed in Italy - directly contributed to the creation of their characteristic musical and dramatic profiles in the minds of Viennese audiences.

The extraordinary popularity of Fra $i$ due litiganti went far beyond Vienna, however: its European success rivaled that of the most popular works by Giovanni Paisiello and Domenico Cimarosa, the other leading figures in the operatic world of the late eighteenth century. The opera's history thus sheds light on broader patterns of operatic transmission and reception that have previously gone unnoticed. For the unexpected fact is that the version of Fra $i$ due litiganti that generated such an enthusiastic response in many corners of Europe was fundamentally different from the version that Sarti created.

\section{Fra $i$ due litiganti from Milan to Vienna}

Giuseppe Sarti (1729-1802) had a long and successful career as a composer of both opere serie and opere buffe, as well as sacred music. Born in Faenza, he studied with Padre Martini in Bologna before returning to his native city, first as organist at the cathedral and then as director of the theater. Il re pastore, his first opera, was performed in Pesaro in $1752 .^{3}$ Sarti spent much of

3. See Pfeiffer, Opere buffe, 10. Pfeiffer provides a concise summary of Sarti's life and career on pages $9-12$. 
the next twenty-five years in Copenhagen, where he directed the Italian opera company and premiered more than two dozen of his own operas, most of them serious. Returning to Italy in 1775 , he achieved a major success with Le gelosie villane (Venice, 1776), and in 1779 became maestro di cappella of Milan Cathedral. His most enduring opera seria, Giulio Sabino (Venice, 1781), was written during this period.

The dramma giocoso Fra $i$ due litiganti il terzo gode (While two dispute the third enjoys the prize) is chiefly known to opera lovers and Mozart scholars because one of its arias, "Come un agnello," is quoted in the dinner music scene of the act 2 finale of Don Giovanni. But Sarti's opera was significant for Mozart and for opera in Vienna for other reasons, too. First, its tremendous popularity made it a model for Mozart and other composers who aspired to their own operatic success in Vienna. Second, its setting and aspects of its story closely resemble those of Le nozze di Figaro, the first of the three great opere buffe that Mozart wrote with Lorenzo Da Ponte. And finally, two of its leading roles were created in Milan, and then reprised in Vienna, by singers central to the history of Viennese opera buffa in the 1780s, Nancy Storace (1765-1817) and Francesco Benucci (ca. 1745-1824).

The libretto of Fra $i$ due litiganti is an anonymous revision of Carlo Goldoni's Le nozze, which was set to music by Galuppi in $1755 .{ }^{4}$ The opera takes place in the palace of Count and Countess Belfiore, and involves a love intrigue in which the chambermaid Dorina (the prima buffa, played by Storace) is pursued by three suitors. Her employers, the Count and Countess, are arguing: the Count wishes Dorina to marry his manservant, Titta (a buffo caricato played by Benucci), while the Countess insists she marry the gardener Mingone-partly in the hope of keeping Dorina at a safe distance from the Count himself. The third lover, the clever steward Masotto, manages everything and everyone and wins Dorina for himself. Titta settles for the hand of a second chambermaid, Livietta, while Mingone is left alone and disappointed. The climactic second-act finale of Sarti's three-act opera (whose brief third act concludes with a coro) takes place, like the fourth-act finale of Figaro, in the woods at night.

A noble couple at odds, a lecherous Count in pursuit of a maidservant, and a scheming underling who gets the best of his master-all these elements are familiar from Figaro, though they must also be understood as standard opera buffa tropes. Dorina in particular is a parallel figure to Mozart's Susanna, though somewhat more passive. She is at the center of the romantic intrigue, determined to resist unwanted suitors (and the inappropriate attentions of

4. See ibid., 45. The libretto for the Goldoni and Galuppi Le nozze is listed in Sartori, Libretti italiani, libretto 16670. (References to this catalog will hereinafter take the form "Sartori [catalog no.].") As Pfeiffer points out, the text of Sarti's opera has sometimes been mistakenly attributed to Giambattista Lorenzi, who wrote the libretto for an entirely different opera entitled Tra $i$ due litiganti il terzo gode (set to music by Gennaro Astaritta for Naples in 1766, Sartori 23361). 
a nobleman) and marry the man of her choice. And, like Susanna in Figaro, she participates in every one of Fra $i$ due litiganti's ensembles: there are two quartets and a trio, in all of which her suitors beg for her affections while she fends them off.

The success of Fra $i$ due litiganti in Milan is evident from the speed with which it was produced at other opera houses. Within weeks of the Milan premiere on September 14, 1782, productions were mounted for the fall seasons at the Teatro Carignano in Turin and the Teatro San Moisè in Venice, the latter under the alternate title of I pretendenti delusi. Fra $i$ due litiganti was then produced in Hanover and Prague early in 1783. It first reached the stage of the Burgtheater in Vienna on May 28, 1783.

The opera's arrival in Vienna coincided with the reestablishment of an Italian opera buffa company there, after a five-year hiatus during which the emperor's National Singspiel presented only operas in German. The emperor named Antonio Salieri music director of the company-returning him to the position he had occupied from 1774 until 1778, when the National Singspiel was instituted-and chose Lorenzo Da Ponte, newly arrived in Vienna, as the house librettist. ${ }^{5}$

The new company began performances on April 22, 1783, with Salieri's La scuola de' gelosi, a reworking of an opera premiered in 1778 in Venice. In the initial season, not surprisingly, all but one of the works presented had been performed previously, most of them elsewhere but in three cases in Vienna back in the 1770s. ${ }^{6}$ Thus the bulk of the work for Salieri and Da Ponte in the first season consisted of the rearranging of existing operas to suit the company's singers and (presumably) the taste of Viennese audiences. ${ }^{7}$ Salieri's La scuola was followed by Cimarosa's L'italiana in Londra (Rome, 1778 ) and then by Sarti's Fra $i$ due litiganti.

While the Salieri and Cimarosa operas were reasonably successful, Fra $i$ due litiganti took the city by storm, almost completely eclipsing its two predecessors. The opera was performed ten times in the first four weeks after its premiere, interrupted only by two performances of La scuola. By the end of the Italian opera company's initial season in February 1784 (the operatic season ran from Easter until the start of Lent the following year), Fra $i$ due litiganti had been performed twenty-eight times-the highest single-season total for any operatic work in the 1780s. Its popularity in Vienna lasted for a number of years: it was heard in five consecutive seasons, omitted in 1788, and performed again nine times in 1789, for a total

5. See Rice, Antonio Salieri, 331-32.

6. The one new work, Josef Barta's Il mercato di Malmantile, to a Goldoni libretto revised by the singer Francesco Bussani, was a failure, lasting for only three performances; see Michtner, Das alte Burgtheater, 167, and Link, National Court Theatre, 36-37.

7. John Rice has shown that in Vienna such rearranging was the responsibility of the music director (often with an assistant) and the theater poet: Rice, "Bearbeitungen italienischer Opern," esp. 81-82. 
of sixty-five performances between 1783 and 1789. Only Martín y Soler's L'arbore di Diana and Paisiello's Il barbiere di Siviglia come close to matching this total, with sixty-five and sixty-two performances respectively in the decade $1783-92 .^{8}$

The version of the opera that Viennese audiences so enjoyed, however, was not the version originally created by Sarti for the premiere in Milan. Six or seven of the opera's solo numbers were replaced in the initial planning for the Viennese premiere, while two others were omitted. ${ }^{9}$ Over the first few months of the opera's run in Vienna, further changes occurred, so that what I will call the established "Viennese version" of Fra $i$ due litiganti contained six arias not present in the original. Three further arias of the original version of the opera were cut.

Making changes to an opera when it was produced in a new city, with a troupe of singers different from those for whom the opera was first written, was standard practice in the eighteenth century (and for some time afterward, at least in Italy). But the changes to Fra $i$ due litiganti are unusual both for their extensiveness, which I discuss below, and for the fact that the Viennese version went on to largely supplant Sarti's Milan original as the opera made its triumphant way to dozens of European opera houses through the remainder of the century.

Table 1 shows the speed with which Fra $i$ due litiganti traveled all over the continent. In the years 1785-86 alone, there were forty-six new productions. And as may be seen, the opera was still popular enough to merit performances as much as seventeen years after its premiere, demonstrating an impressively long life span for a late eighteenth-century opera buffa.

The first of numerous productions of Fra $i$ due litiganti in German, with spoken dialogue rather than recitatives, appeared in 1784 at the Fasan Theater in Vienna in a translation by Ludwig Zehnmark entitled Wenn sich zwey streiten, freut sich der dritte. ${ }^{10}$ Another translation, by Johann André, entitled Im Trüben ist gut fischen, first appeared in 1785 and circulated more widely, being used in Cologne and Amsterdam among other cities, as well as in a second German production in Vienna at the Kärntnertortheater in 1787. The Zehnmark translation of the opera was produced in Salzburg and elsewhere. And in 1786 a French translation and arrangement of the opera

8. Three other works received more than fifty performances in Vienna in this decade: Paisiello's Il re Teodoro in Venezia (fifty-nine), Martín's Una cosa rara (fifty-five), and Salieri's Axur, re d'Ormus (fifty-one). These performance totals come from Link, National Court Theatre. But as Dexter Edge has pointed out in "Mozart's Fee," performance totals are a far less accurate gauge of a work's popularity than box office receipts. Unfortunately, these do not survive for the early 1780s.

9. The question of whether it was six or seven arias is addressed below.

10. The performance information in this paragraph derives from my own examination of the primary sources listed in the "Works Cited" list below, and from Loewenberg, Annals of Opera, cols. 397-98. 


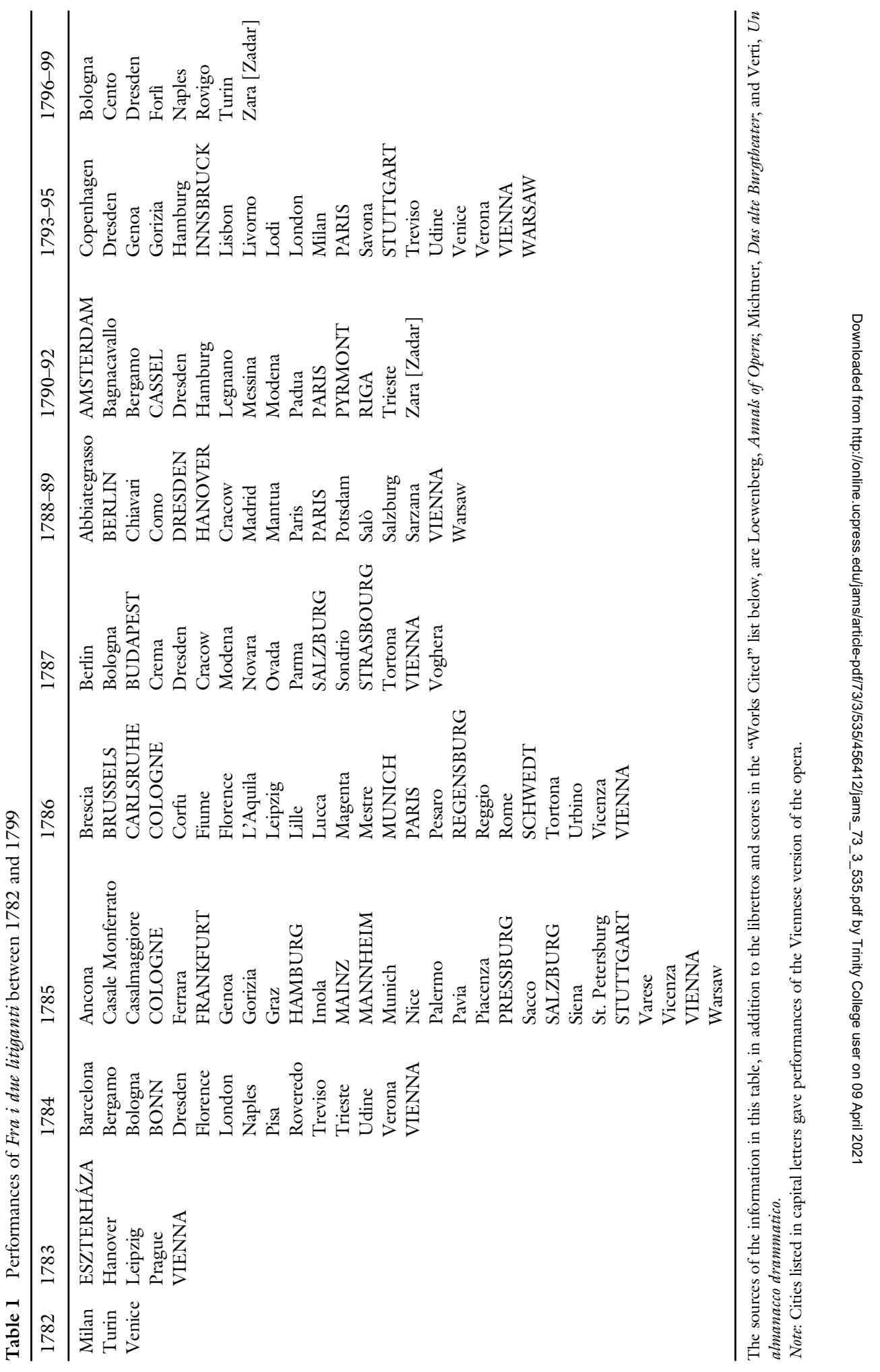


by Pierre-Ulric Dubuisson, as a four-act work called Hélène et Francisque, was performed in Paris and Brussels. The Parisian music publisher Sieber published a full score of this French version in 1789, attesting to its widespread popularity. Paris actually saw multiple productions, with performances in Italian in 1789 as Le nozze di Dorina, ovvero I tre pretendenti. The work was still being performed in Paris, apparently in both languages, well into the nineteenth century. We can add to this list performances in Danish, in Copenhagen, where Sarti had spent many years and where his music must have been very popular; in Polish, in Warsaw; and in Russian, in St. Petersburg, where Sarti was working for Catherine the Great. By any measure, Fra $i$ due litiganti was among the most widely performed and best-loved opere buffe of the late eighteenth century, heard in nearly every corner of Europe.

But as Table 1 shows, many of these productions presented the Viennese version of the opera, rather than Sarti's Milanese original or anything close to it. The cities listed in capital letters are those for which sources confirm that the version was the Viennese one. (Many others of these productions were undoubtedly based on the Viennese version, but no libretto or other source remains to confirm this.) Tables 2 and 3 reveal another aspect of the two very different transmission patterns of Fra $i$ due litiganti. Table 2 shows the relationship between the Milan original and forty-eight sources closely related to it. As may be seen, only the ensembles and finales remain unchanged in subsequent productions. When arias were substituted, the new pieces varied from production to production; in only seven cases did the same substituted piece appear more than once. Thus, it is reasonable to conclude that substitutions were made for local reasons, to suit the needs of the singers in any given city who were taking on the roles. ${ }^{11}$ Table 3 compares the Viennese version of the opera with sources based on it found in other cities. While Table 2's sources for productions based on the Milan original routinely contain substitute pieces, the sources in Table 3 transmit the Viennese version with virtually no changes. From time to time particular arias are omitted, but none is ever replaced. In short, while the sources based on the Milan version reflect our widely accepted understanding of how opere buffe were altered in their travels from one opera house to another, the sources based on the Viennese version present a fundamentally different picture. ${ }^{12}$

11. Rice, "Bearbeitungen italienischer Opern," offers a detailed description of the way decisions about substitutions were made in Vienna in the period 1765-1800, also discussing smaller adjustments to operas such as cuts in recitative and the transposition of musical numbers.

12. Tables 2 and 3 must be read with some caution, not with respect to the overall patterns but with respect to the accuracy with which any individual libretto or score reflects the pieces actually performed in a given production. In general, a libretto is more likely to accurately reflect a production in a given city than a score, since a score-especially one without any revisions or performance indications - may have simply been the "raw material" acquired from another city. But as the discussion of the Viennese librettos below makes clear, librettos cannot be fully relied upon either. For instance, several librettos in table 2 contain the text for Dorina's "Sento Amore 
Table 2 The Milan version of Fra $i$ due litiganti and related librettos and scores

Milan version

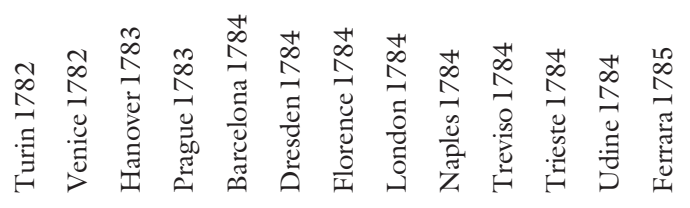

\section{ACT 1}

Introduzione: La voglio

Count: Vuò soffrire

Countess: Ah dove è andato

Livietta: Io voglio

Quartet: Dorina

Masotto: Un assedio

Dorina: Sento/Non fidarti

Mingone: Come un agnello

Titta: Quel che / Quando ${ }^{\mathrm{a}}$

Dorina: E' destin

Finale 1

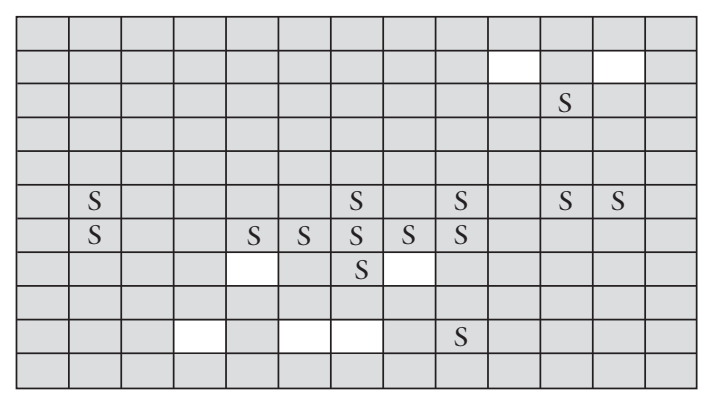

\section{ACT 2}

Countess: Non avrò riposo

Masotto: Dove sei?

Livietta: Son una

Quartet: Ah Dorina

Titta: Per voi visetto

Livietta: Un diavolino

Masotto: Servo umilissimo

Titta: La sposerò

Count: Bada bene

Mingone: Un giardinier

Dorina: recitative, Ahimè rondò, Sola in braccio

Finale 2

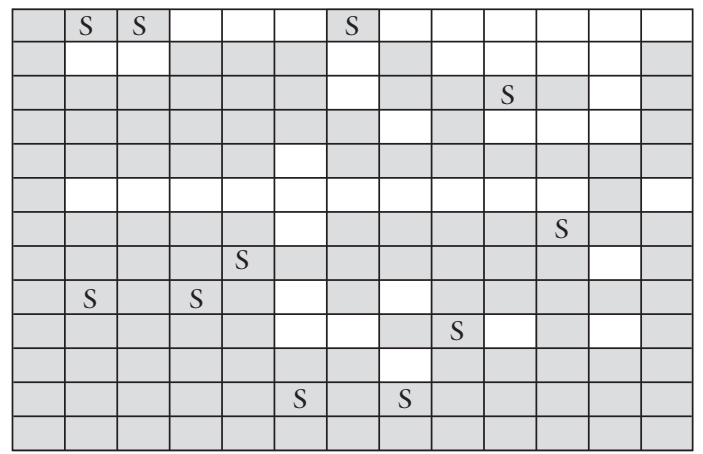

ACT 3

Trio: Che vi par

Coro: Amore / Più tra noi

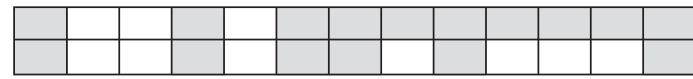

Note: Librettos are listed by year, then alphabetically by city. Scores are listed alphabetically by city. A shaded box represents no change from the Milanese version; " $S$ " indicates a substituted number; a white box indicates omission of a number. Where a number was moved to a different location within the opera, it is shown here as if in the original location.

a There are two original alternatives for Titta's act 1 aria, "Quel che mi bolle in testa" and "Quando saprai chi sono."

che mi dice" in act 1 and for the act 3 coro "Amore discenda." Yet no music survives for either piece, and there is no reason to believe that either was ever performed. In all likelihood, these texts were printed in their librettos as placeholders while the production was being prepared, and would have been replaced or cut by the time of the premiere. It is also the case that librettos and scores from the same city rarely match exactly in their contents. In table 2 , in only two cases out of nine (Dresden and Stuttgart) is there an exact match. 


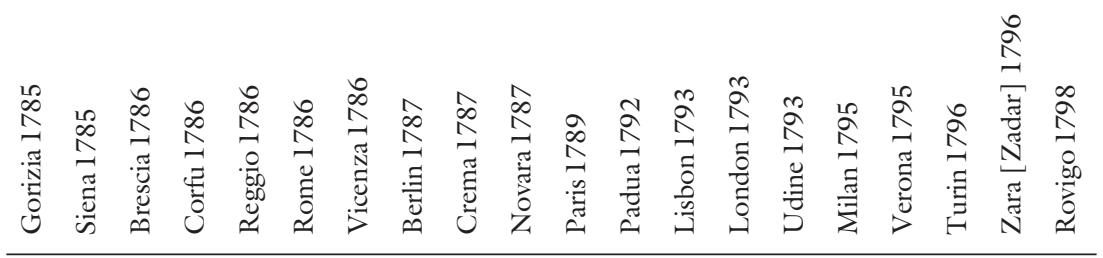

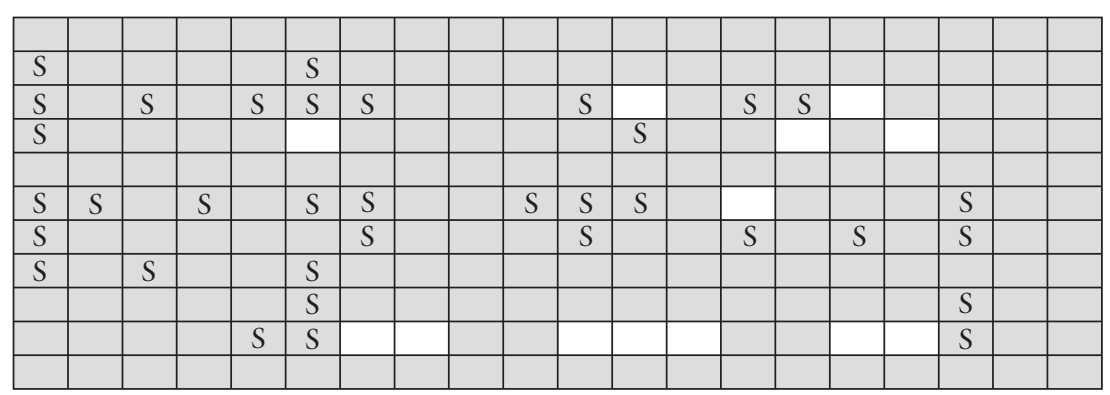

\begin{tabular}{|l|l|l|l|l|l|l|l|l|l|l|l|l|l|l|l|l|l|l|l|}
\hline & & & S & & S & & S & S & & & & S & & & S & & & & \\
\hline & & & & & & & & & & S & & & S & S & & & S & & \\
\hline & & S & & & & & & & S & & S & & & & & & & & \\
\hline & & & & & S & & & & & & & & & & & & S & & \\
\hline & & & & & & & & & & & S & & S & & & & S & & \\
\hline & & S & & & & & & & & & & & & & & & & & \\
\hline & & & & & & & & & & & S & & & & & S & S & & \\
\hline & & & & & & & & & & & & & & & & & S & & \\
\hline & & & & & & & & & & S & & & & & & & & & \\
\hline & & & & & S & S & & & & & S & & & & & & & & \\
\hline & & & & & & & & & & & & & S & & & & & & \\
\hline & & & & & & & & & & S & & S & S & & S & & S & & \\
\hline & & & & & & & & & & & & & & & & & & & \\
\hline
\end{tabular}

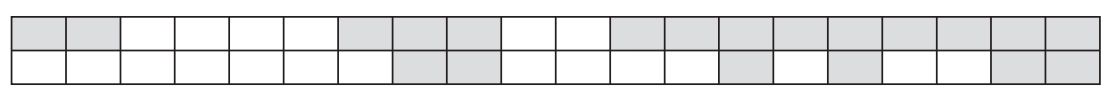

(continued)

There are several possible explanations for this difference. First, at least some of the opera houses that produced the Viennese version may have lacked the resources to commission new substitute arias. But this would not seem to be the case in larger cities like Paris or Berlin, both of which 
Table 2 continued

Milan version

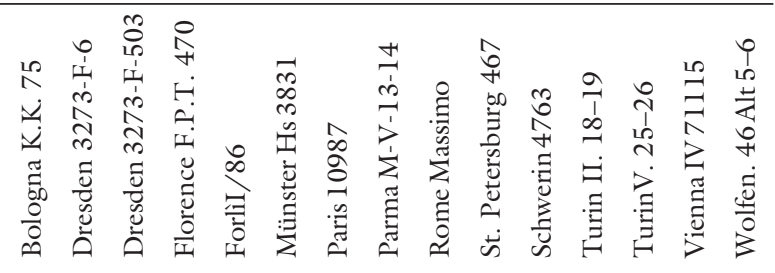

\section{ACT 1}

Introduzione: La voglio Count: Vuò soffrire Countess: Ah dove Livietta: Io voglio Quartet: Dorina

Masotto: Un assedio Dorina: Sento / Non Mingone: Come Titta: Quel / Quando Dorina: E' destin Finale 1

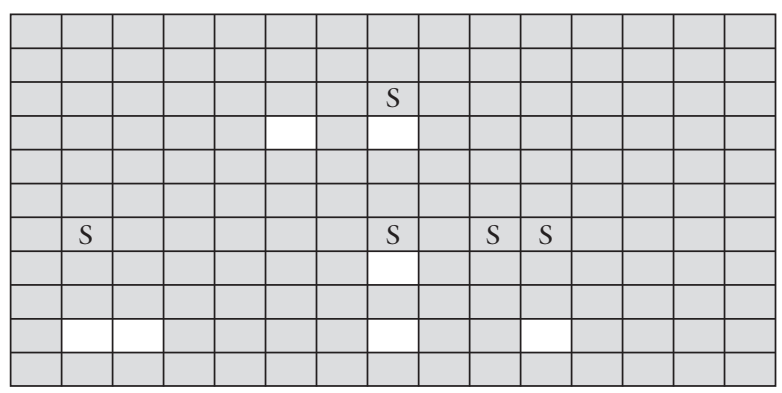

\section{ACT 2}

Countess: Non avrò Masotto: Dove sei?

Livietta: Son una Quartet: Ah Dorina Titta: Per voi visetto Livietta: Un diavolino Masotto: Servo Titta: La sposerò Count: Bada bene Mingone: Un giardinier

Dorina: recitative, Ahimè Finale 2

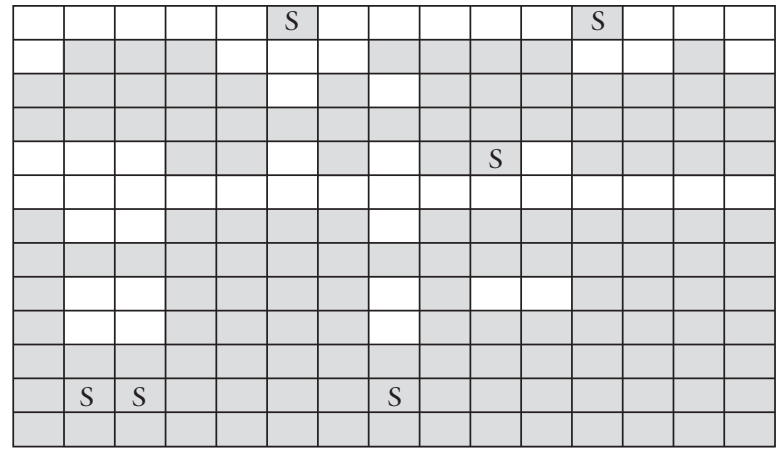

ACT 3

Trio: Che vi par Coro: Amore / Più

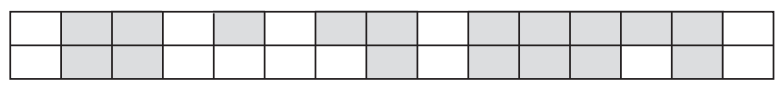

presented the Viennese version without any substitutions (though the order of pieces was rearranged in the French four-act version). ${ }^{13}$ Moreover, even in

13. In fact, each of these cities offered two distinct versions of Sarti's opera. Berlin saw a 1787 production of the opera in its Milan version, with just one substituted aria, and a year later a production in German of the Vienna version, using the André translation. In Paris, the French Hélène et Francisque mentioned above was based entirely on the Vienna version, while the 1789 production of Le nozze di Dorina used the Milan version of the score. 
cities where there were no composers capable of rapidly producing a substitute aria, one would expect that the singers themselves could have provided their own preferred "suitcase" arias as substitutes well suited to their voices. ${ }^{14}$

The exceptional case of Regensburg, the only opera company I have found that used the Viennese version yet made substantial changes to it (see table 3), points to possible reasons for the general pattern. The Hoftheater (court theater) of Prince Carl Anselm of Thurn und Taxis produced a variety of Italian operatic genres in 1774-78 and again in 1784-86 (German theater was performed in the interregnum). ${ }^{15}$ The company's musicians were an impressive group, including Ludwig Fischer, who had previously sung important roles in Vienna, including Osmin in Mozart's Die Entfübrung aus dem Serail. Led by the composer Theodor von Schacht (1748-1823) and supported by a substantial budget, the Thurn und Taxis opera company "staged performances of the newest operas from across Europe," in addition to operas by Schacht and other local composers. ${ }^{16}$

Two key Regensburg sources for Fra $i$ due litiganti survive: the score in the Fürst Thurn und Taxis Hofbibliothek (call number Sarti 5), whose contents match those of the Viennese version exactly; and the libretto from the Regensburg production of 1786, which contains six arias not in the Viennese version. (Both are shown in table 3: the libretto is the fifth column, and the score is in the fifth column from the right.) Surprisingly, the texts of three of these six arias can be found in Fra $i$ due litiganti librettos from other cities: one each from the earlier Vienna libretto (discussed below), the Venice 1782 libretto, and a 1785 libretto from Gorizia. (The Venice and Gorizia librettos are shown in table 2.) The remaining texts are otherwise unknown.

Separate scores for three of the arias also survive in the Regensburg Hofbibliothek. One of these is a setting by Schacht himself for the Countess's aria "Io non spiro che rabbia e veleno." Interestingly, this text appears in the first Vienna libretto of 1783 but seems never to have been set to music or performed in Vienna. The other two are arias taken from existing operas: one from Schacht's own La semplice (1775), and one by Anfossi from his $\mathrm{Il}$ curioso indiscreto (Rome, 1777). Music for the remaining three substitute arias does not appear to survive. This evidence suggests that Schacht, the

14. The term "suitcase aria" ("aria di baule") refers to the well-known practice of opera singers traveling from one opera house to another with their favorite arias, which they substituted as desired for the originally composed arias in the operas they were performing. The practice was common from the seventeenth century until well into the nineteenth. See, among others, Brown, "On the Road"; Freeman, "Farinello and His Repertory"; Butler, "From Guadagni's Suitcase"; Genesi, Una primadonna tardosettecentesca; Emerson, "Migrating Mozart"; and Poriss, Changing the Score.

15. The information on the opera establishment at Regensburg in this paragraph comes from Glatthorn, "In the Name of the Emperor," 1-8, and Meixner, Musiktheater in Regensburg, 161-69, 200-21.

16. Glatthorn, "In the Name of the Emperor," 8. 
Table 3 The Vienna version of Fra $i$ due litigantiand related librettos and scores

Vienna version

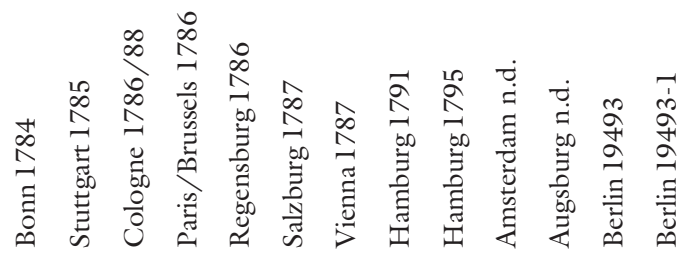

\section{ACT 1}

Introduzione: La voglio Count: La donna

Countess: Vorrei punir

Livietta: Io voglio

Quartet: Dorina

Masotto: In amor

Dorina: Compatite

Mingone: Come un agnello

Titta: Quando / Dunque

Dorina: E' destin

Finale 1

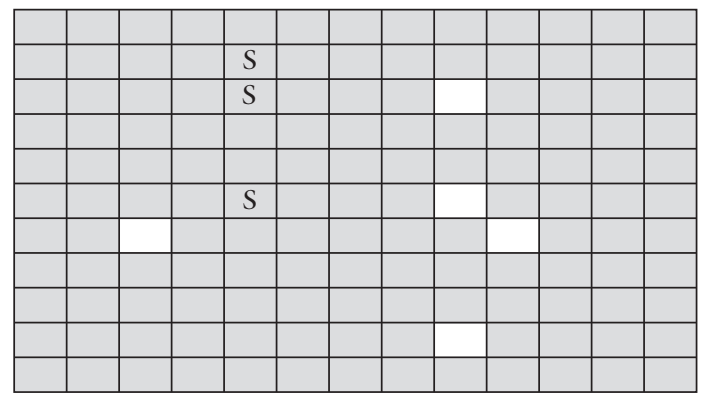

\section{ACT 2}

Masotto: L'onda placida

Livietta: Son una

Quartet: Ah Dorina

[Countess aria, cut] ${ }^{\mathrm{b}}$

Masotto: Servo umilissimo

Titta: La sposerò

Count: Bada bene

Mingone: Un giardinier

Dorina: recitative, Ahimè

Finale 2 rondò, Non potrò

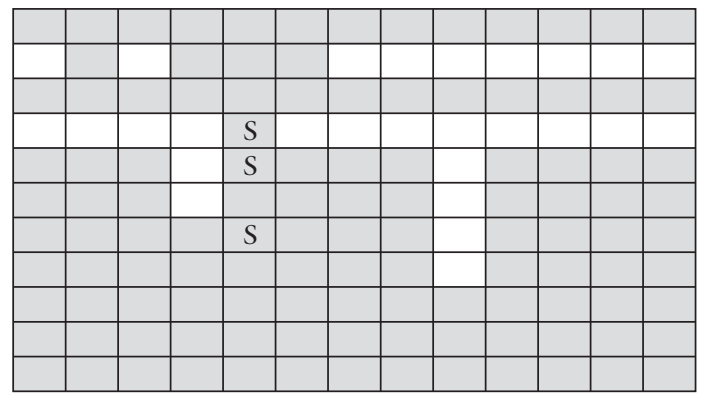

ACT 3

Trio: Che vi par

Coro: Più tra noi

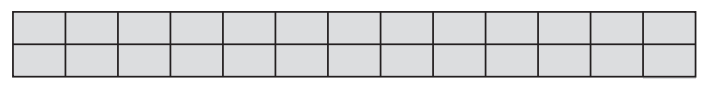

Note: Librettos are listed by year, then alphabetically by city. Scores are listed alphabetically by city. A shaded box represents no change from the Vienna version; "S" indicates a substituted number; a white box indicates omission of a number. Where a number was moved to a different location within the opera, it is shown here as if in the original location.

a There are two original alternatives for Titta's act 1 aria, "Quando saprai" (in A-Wn Mus. Hs. 17888, the main source for the Vienna version: see below) and "Dunque aspettate" (in other Viennese sources).

$\mathrm{b}$ The Countess's act 2 aria was cut before A-Wn 17888 was copied.

music director of the opera company, played a decisive role (no doubt in consultation with the singers) in providing substitute pieces as needed for the Regensburg production. In addition to obtaining a score of the opera from Vienna, the Hoftheater clearly had access to at least three librettos, 

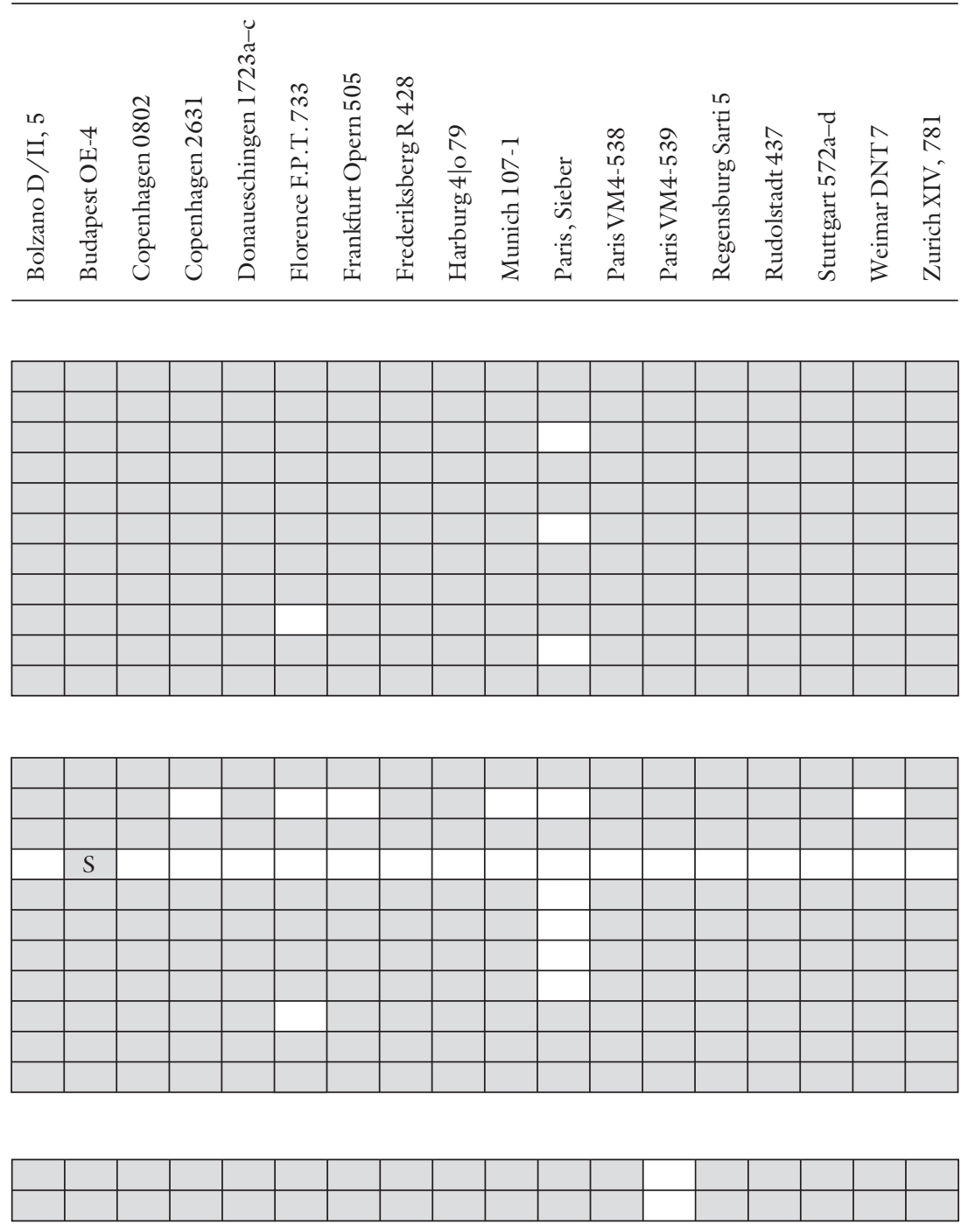

which Schacht (and perhaps other composers) made use of in borrowing or newly composing the desired arias.

The example of the Regensburg production suggests what must have been needed to mount a production of Fra $i$ due litiganti, or any other opera, while extensively altering it: not only a competent music director willing and able to make the changes, but the financial resources to acquire the necessary sources and to commission librettists and composers to write new arias. Schacht, like Haydn at Eszterháza, seems to have been such a music director. 
Presumably, some of the smaller opera houses represented by the sources in table 3 would have lacked such resources. But this does not explain why larger companies, like those in Berlin or Paris, performed the Viennese version without making any changes to suit local singers. ${ }^{17}$ It is possible that singers were not afforded the same status - and in particular the same power to request or demand changes to their music - in some opera houses as in Italy and Vienna. It may have been understood in Cologne or Salzburg, for example, that singers had to sing the parts given to them.

The widespread adoption of the Viennese version in theaters across Europe - and the nearly universal use of that version without changes - may also reflect the city's prestige and cultural importance, as the largest Germanspeaking city in the world and capital of the vast Habsburg Empire. Its opera company employed many of the best and highest-paid singers in Europe. For theaters in other German-speaking cities, it would have been logical to acquire scores from Vienna rather than from Italy. But even theaters in Copenhagen and Paris bought opera scores from Vienna, suggesting that the imperial capital was the most convenient and reliable source, rather than the cities in Italy where most of the repertoire originated. Moreover, each of these houses could rightly claim that it was offering its audiences Sarti's Fra $i$ due litiganti "as seen in Vienna." Ultimately, other studies of operatic transmission in the late eighteenth century will be needed before we can understand whether the pattern shown by this particular opera is representative or unusual, and what its causes were.

\section{The Sukowaty Copying Firm}

Many of the scores that transmit the Viennese version of Fra $i$ due litiganti were produced by a team of professional copyists in the employ of Wenzel Sukowaty (1746-1810, sometimes spelled "Suckowaty"), who was the official copyist of the Viennese court theaters from 1778 to about $1796 .{ }^{18} \mathrm{Su}-$ kowaty's arrangement with the court called for him to produce all the necessary materials for opera performances in Vienna, including scores and

17. The question is particularly interesting in that the productions of the Milan version in those cities did contain substituted pieces: one aria in the 1787 Berlin production, and no fewer than six in the 1789 Paris production, with music by Ferrari, Zingarelli, and Viotti; see Loewenberg, Annals of Opera, col. 398. It may be that these productions in Italian featured the most celebrated singers, who were felt to have the right to insist on changes to their roles-for example, the 1789 Paris production featured Stefano Mandini, who had been Mozart's first Count Almaviva in Vienna-while singers in productions in vernacular languages did not have the same clout.

18. See Edge, "Mozart's Viennese Copyists," 117-18 (birth and death dates on 1295 and 1306 respectively). Most of what we know about Sukowaty can be found in this dissertation. 
orchestral and vocal parts. (For most operas the court also ordered an archival copy of the score.) He was then free to produce, for his own profit, what Dexter Edge calls "commercial copies" of scores in response to orders from outside Vienna. In many of these copies, the title page is inscribed with a statement of origin, typically reading something like "In Vienna, available from Wenzel Sukowaty, copyist at the Imperial National Theater." 19

To undertake the extensive amount of music copying that was required by Viennese theaters, Sukowaty employed a stable of copyists. Edge has identified twenty or twenty-one separate hands in the Sukowaty manuscripts associated with Mozart; and in all likelihood many more appear in other scores and parts produced by his shop. ${ }^{20}$ The notion of a "shop" is metaphorical, however: as Edge explains, we do not know where the copying went on. Individual copyists may have worked at the Burgtheater or at some other central location where the performing scores were kept; or they may have worked in their own homes. ${ }^{21}$ The fact that many scores contain a number of different ink colors suggests that the latter may have been more common. ${ }^{22}$

Preparing an opera for performance in Vienna began with the acquisition or creation of a performing score. For a newly composed work, that score would be copied by Sukowaty's team from the composer's autograph; for works imported from elsewhere, the performing score would be purchased. In the case of Fra $i$ due litiganti, the score now cataloged in the Musiksammlung of the Österreichische Nationalbibliothek as KT 357-an Italian score probably of Venetian origin - was used as the performing score in Vienna throughout the 1780s. In all likelihood it was one of several opera scores purchased in Venice and sent to Vienna by the Austrian ambassador to Venice, Count Giacomo Durazzo (1717-94). ${ }^{23}$ As is typical of performing scores, KT 357 survives in a much marked-up and altered state, reflecting successive changes over a number of seasons of performances. ${ }^{24}$ (I discuss the details of these changes below.)

19. This is the inscription on the title page of the score copied for Eszterháza, which is now in Budapest (H-Bn Ms. Mus. OE-4): "Wienn. zu haben bey Wenzel Sukowaty Copist in K. K. Nazional Theater."

20. Edge, "Mozart's Viennese Copyists," appendix D and passim. According to Rice, a single Sukowaty score of Salieri's Axur (Vienna, Österreichische Nationalbibliothek, Musiksammlung, Mus. Hs. 17832) contains nine distinct hands: Rice, "Bearbeitungen italienischer Opern," 90.

21. Edge, "Mozart's Viennese Copyists," 68-69, 109.

22. For the reasoning behind this tentative conclusion, see ibid., 188.

23. See ibid., 2193.

24. Rice distinguishes between a "source score" and a "performing score"; the former "documents the state of the opera before the Viennese editing process began": Rice, "Bearbeitungen italienischer Opern," 86. In the case of Fra $i$ due litiganti, as in some others, the source score was used as the performing score. 
The performing score served as the Vorlage (template) for all further copying of scores and parts for use in Vienna. ${ }^{25}$ And it was also used as the basis for the commercial copies prepared by Sukowaty's copyists to be sent to theaters in other cities. In the case of Fra $i$ due litiganti, I have identified ten scores copied by Sukowaty's firm that now survive in libraries outside Vienna (see the "Works Cited" list below). Three of these name Sukowaty on the title page; the others are recognizable from the configuration of characteristic features of musical handwriting that Edge has identified as typical of Viennese copyists. $^{26}$

Certain details of the Sukowaty scores provide fascinating glimpses into the workings of the copying business. Scores were clearly produced in response to individual orders and with the needs of the client in mind. For a theater intending to perform Fra $i$ due litiganti in the original Italian, the score was copied complete, containing both the musical numbers and the simple recitative, with the words underlaid throughout. But for theaters planning to perform the work in German, Sukowaty's shop produced copies that contained only the musical numbers; the recitatives are omitted, because performances in German would have employed spoken dialogue. Some of the scores in German retain the original Italian names for the characters; but others omit them entirely, since the characters had different names in Johann André's German translation (Dorina became Hannchen, Titta was Heinrich, and so forth). In these scores the German words and character names were subsequently entered in a hand completely different from those that copied the music. One German score shows a mistake where a Viennese copyist erroneously included the character name Dorina at the beginning of her accompanied recitative in act 2 , while she is named correctly as Hannchen at the beginning of the aria. Another score shows a different but equally obvious copyist's mistake: the act 2 aria for the Count, "Bada bene a quel che dico," includes the original Italian text for the first seven measures, in addition to the complete German text. ${ }^{27}$

There is no doubt that the provision of scores without the Italian text was intentional and by request. This is made clear in Titta's aria in act 1, "Quando saprai chi sono." In the middle of this long, multisectional piece full of bluster and braggadocio, Titta demonstrates his singing ability by quoting part of an aria from Sarti's own Achille in Sciro (Florence, 1779), one famously associated with the great castrato singer Luigi Marchesi. ${ }^{28}$ Even in productions of Fra $i$ due litiganti in German, this quoted passage

25. See also the discussion in Rice, "Bearbeitungen italienischer Opern." The likelihood that Sukowaty made an intermediate copy for his own use is explored below.

26. Edge, "Mozart's Viennese Copyists," esp. 260-63.

27. These errors are found respectively in a score from Berlin (D-B Mus. Ms. 19493) and one from Stuttgart (D-SI HB XVII $572 \mathrm{a}-\mathrm{d}$ ).

28. See Pfeiffer, Opere buffe, 142-43. Titta's aria is discussed in greater detail below. 
would have been sung in the original Italian; accordingly, the Sukowaty copyists supplied its text.

These differences in language and the names of the characters suggest that a score could be ordered from Sukowaty in a variety of formats, depending on the needs of the opera house. And the existence of Sukowaty scores in such places as Berlin, Copenhagen, and Paris, in addition to cities closer to Vienna like Regensburg and Budapest, confirms that Sukowaty's firm must have been widely known as the principal source for scores of the latest Viennese operatic works.

\section{The Creation of the Viennese Version}

The early history of Sarti's opera in Vienna and the creation of the Viennese version that was exported to other European theaters can be traced in a small set of key sources, shown in table 4 . A careful analysis of these permits us to reconstruct in considerable detail the process by which Fra $i$ due litiganti reached its widely distributed form. ${ }^{29}$

Even before Fra $i$ due litiganti reached Vienna in 1783, alteration of the opera had begun. The production in Turin apparently involved no changes, ${ }^{30}$ but the production at the Teatro San Moisè in Venice contained several. The opera was presented under the alternate title I pretendenti delusi, and its libretto reveals four substitute aria texts, one each for the lovers Dorina and Masotto and for the Count and Countess. ${ }^{31}$ An additional change in the Venice production, rather hard to fathom from our modern point of view, was the dropping of the final act. The lengthy finale to act 2 concludes with the plot completely unresolved-no decision has been reached as to who will marry Dorina-and with the entire cast in the woods outside the Count's palace, fleeing a frightening thunderstorm. Only in the brief third act does Masotto persuade the Count and Countess that he himself is the best candidate for Dorina's hand. (Act 3 contains just two musical numbers: a comic trio for Dorina, Masotto, and Titta, in which the latter

29. Albrecht-Hohmeier and Siegert, "Eine codierte Opernedition," provides a detailed comparison of several manuscript scores of the opera. The article discusses plans for a digital edition of several scores of Fra $i$ due litiganti that, as of this writing, has not yet been completed. At certain points, the analysis below overlaps with the "theory of transmission" put forward by Ian Woodfield in his work on Mozart's Don Giovanni. Woodfield's distinction between a "conducting score" whose role is part of the process of "fluid re-creation" and a "reference score" as the source for "static replication" of the opera is relevant here, too, though a key difference is that the autograph score of Fra $i$ due litiganti plays no role in the story of its Viennese adaptations. See Woodfield, Vienna "Don Giovanni," esp. 142.

30. The 1782 Turin libretto (Sartori 10900) follows the Milan libretto exactly, while the two scores in Turin (I-Tf 1. II. 18-19 and I-Tf 1. V. 25-26) use the later of the two act 1 arias that Sarti wrote for Titta (discussed below).

31. Sartori 19051; no Venetian score survives. 
Table 4 Principal sources for the Viennese version of Fra $i$ due litiganti

\begin{tabular}{|c|c|}
\hline Dates & Manuscript scores and printed librettos \\
\hline \multirow{3}{*}{ early spring 1783} & A-Wn KT 357 \\
\hline & Fra Li due Littiganti Il Terzo Gode \\
\hline & (an Italian score, used as the performing score in Vienna) \\
\hline \multirow[t]{3}{*}{ before May 28, 1783} & FRA I DUE / LITIGANTI / IL / TERZO GODE \\
\hline & (Vienna: Giuseppe Nob. de Kurzbeck, 1783) \\
\hline & Vienna, Österreichisches Theatermuseum, 629565-A \\
\hline \multirow[t]{3}{*}{ early July $1783^{\mathrm{a}}$} & FRAI DUE / LITIGANTI / IL TERZO GODE. \\
\hline & (Vienna: Giuseppe Nob. de Kurtzbeck, 1783) \\
\hline & Vienna, Gesellschaft der Musikfreunde, ТB 16.972 \\
\hline \multirow[t]{2}{*}{ early July $1783^{\mathrm{a}}$} & H-Bn Ms. Mus. OE-4 \\
\hline & $\begin{array}{l}\text { Fra Li Due Littiganti il Terzo Gode ... Wienn. zu haben bey } \\
\text { Wenzel Sukowaty Copist in K. K. Nazional Theater } \\
\text { (a Sukowaty score made for Eszterháza) }\end{array}$ \\
\hline \multirow[t]{2}{*}{ after early July 1783} & A-Wn Mus. Hs. 17888 \\
\hline & Frà i due Littiganti Il Terzo Godè \\
\hline
\end{tabular}

${ }^{a}$ It is not possible to determine whether the second Kurzbeck libretto is earlier or later than the score now in Budapest. The libretto contains Dorina's aria "Non fidarti Amor mi dice," while the score includes her "Compatite miei signori" (discussed below), which replaced it between June and mid-July. On the other hand, the score contains the aria "Dunque ascoltate o cara" for Titta, while the libretto has its July replacement aria, "Quando saprai chi sono." There are two other discrepancies between the sources, suggesting opposite conclusions as to their relative chronology.

mistakenly believes that his wooing of Dorina has been successful; and a final homophonic coro.) Thus the version of the opera in which all of act 3 is omitted-an omission found in a number of other productions-does not even pretend to supply the lieto fine (happy ending), in the form of a marriage, that has long been assumed to be a fundamental part of the ethos of opera buffa. It ends in a musically satisfactory fashion, with a lengthy finale that closes with an exciting stretta, but without any sort of dramatic resolution of the story. And there is no doubt that the dropping of act 3 was intentional: the Venice libretto concludes, after the act 2 finale, with the words "Fine del dramma." 32 It is possible that further research will reveal that the short third act was actually performed, even where no text appeared in the libretto. But at present, the reason for the omission remains a mystery.

The story told by the sources listed in Table 4 reveals that the alterations made to Fra $i$ due litiganti in Vienna came in three chronological stages: the initial planning for the production; the period shortly before the premiere, presumably during rehearsals; and the first weeks of the run of the opera. Moreover, these sources raise two central questions. First, why were changes made to the roles of Dorina and Titta, since they were sung in Vienna by the

32. Seventeen other librettos that I have examined conclude in the same fashion, all of them based on the Milan rather than the Vienna version of the opera. 
same two singers (Storace and Benucci) who had created the roles in Milan? Second, why was the development of the Viennese version such an elaborate, ongoing process? Typically, the changes planned in an opera imported from elsewhere would be reflected in the printed libretto and the altered performance score, whose contents would match. But in the case of Fra $i$ due litiganti the situation was more complex.

As table 4 shows, the earliest source is the score now cataloged in Vienna as KT 357. It is a score of Italian provenance that was clearly used as the performing score for Fra $i$ due litiganti's first stagings in Vienna, as it shows numerous cuts, alterations, substitutions, and performance indications. While substantial portions of the original opera remain, in the handwriting of one or more Italian copyists, many other pieces have been removed and replaced-in some cases several times, as is evident from numerous annotations, cross-outs, and cuts that have been made by pasting over or folding and stitching pages down. KT 357 may have been copied in Venice, since the score's wrappers give the Venetian title I pretendenti delusi, though the title page of volume 1 calls the opera "Fra Li due Littiganti" [ $s i c]$ and cites the Milan production. The score's multiple layers cannot be completely disentangled, but there are at least four: the original version as it arrived from Italy; a second stage at which KT 357, with an initial set of substitutions written by Viennese copyists, served as the Vorlage (either directly or, more likely, via an intermediate score made by Sukowaty and in his possession) for the required orchestral and vocal parts; a third stage, at which subsequent additional substitutions made in KT 357 were added to the revised intermediate score and appeared in the "archival" score now in the Musiksammlung of the Österreichische Nationalbibliothek, Mus. Hs. 17888 (see below), and numerous commercial copies; and, finally, one or more layers in which further changes and substitutions were made, presumably for later performances in Vienna. These changes include the addition of a German text, entered no doubt at the time of the opera's performances as Im Trüben ist gut fischen. Since KT 357 appears to have been used for performances at least through the end of the 1780s, it is impossible to know what it looked like at any particular point.

On the basis of the sources, the most likely chronology of events would seem to be as follows. When the purchased score of Fra $i$ due litiganti (KT 357 ) reached Vienna, Salieri and Da Ponte would have decided on the necessary alterations, no doubt in consultation with the singers. ${ }^{33}$ Substitute arias would either have been commissioned and composed (with texts by Da Ponte), or have been taken from existing scores. Once complete, the substitutions would have been given to Sukowaty, whose copyists would have made copies of the new pieces and inserted them into KT 357, discarding any rejected material from the Italian source. (As just described, the current state of KT 357 makes clear that this substituting took place.) At that point, in all 
likelihood Sukowaty would have made for his own use what I will call an intermediate copy, based on KT 357 with the initial changes just described. The intermediate copy would have served as the basis for the parts made for the Viennese opera orchestra and singers; and Sukowaty would have used it as the Vorlage for the commercial copies he sold to other opera houses. Since not all the commercial copies Sukowaty produced are identical in their contents, he must have updated the intermediate score from time to time as changes were made to the version of the opera being performed in Vienna. It is possible, though it seems unlikely for practical reasons, that Sukowaty never made an intermediate score, instead relying on the performing score KT 357 as the Vorlage. But with the latter in constant use at the opera house for rehearsals and performances, it would have been difficult for Sukowaty's copyists to have the free access to the score that would have been necessary in order to produce the many commercial copies that survive. ${ }^{34}$

The archival score, 17888 , is a clean copy produced by Sukowaty's firm. In all likelihood it was copied from the Sukowaty intermediate score made from KT 357; the vast majority of pages in 17888 are laid out exactly like those in KT 357, and both recitatives and musical numbers have line and page breaks at the same points, some of them awkward ones. ${ }^{35}$ An additional Sukowaty score now in Budapest (Országos Széchényi Könyvtár, Ms. Mus. OE-4) was produced no later than early July 1783 and sent to Eszterháza, where it presumably served as the basis for Haydn's production of the opera, first performed on August 10, 1783. (One of the Eszterháza parts is dated July 20.) This production, only seventy-four days after the premiere in Vienna, may give additional evidence of the opera's extraordinary success in the Habsburg capital. It is possible that the score was ordered from Vienna even before Fra $i$ due litiganti had premiered there; that is, Haydn or his princely employer may have wanted to produce it on the basis of reports of the opera's success in Italy. But the contents of the score make clear that, whenever it may have been ordered, it was actually copied well after the premiere-probably in early July.

Unusually for opere buffe produced in Vienna, there were two distinct versions of the libretto of Fra $i$ due litiganti, both printed by Kurzbeck in $1783 .{ }^{36}$ This may have been because, on account of the opera's popularity,

34. To my knowledge, no intermediate scores of the type I describe have survived and been identified as such. On the other hand, there is no particular reason to assume they would have been regarded as worth preserving, once the popularity of an opera had waned and no future production was considered likely. I am grateful to Ulrich Leisinger for sharing his views on this question.

35. This conclusion is also proposed in Link, Arias for Nancy Storace, 113.

36. Rice notes that "Viennese librettos ... seem to have been rarely produced in more than one edition. The opera might have evolved, but the libretto stayed the same": Rice, "Bearbeitungen italienischer Opern," 97 ("[Viennese] Libretti nicht in Neuauflagen erscheinen zu lassen, auch wenn die zugrunde liegende Oper revidiert worden ist"). An exception seems to be the two printed librettos for Mozart's Cosi fan tutte; but the first of these, according to Bruce 
the first printing sold out. The earlier version was evidently printed shortly before the opera's premiere in late May 1783, the later one probably about six to eight weeks later. (This second libretto is easily distinguished from the first by its title page, where "FRA I" is printed as "FRAI" and the printer's name given as "Kurtzbeck.") ${ }^{37}$

In addition to these sources, invaluable information about the early changes to the opera may be gleaned from the diaries of Count Karl Zinzendorf, who assiduously attended the theater and opera in Vienna and whose detailed comments have long been cited by Mozart scholars. Zinzendorf (1739-1813) had a lengthy career as a government official under the Habsburgs; from 1781 he was president of the Hofrechnungskammer (Court of Audit). ${ }^{38}$ While he was no musician — not even a knowledgeable amateur, as Dorothea Link makes clear-he was a careful observer, who frequently remarked on the performances of particular singers or actors and even (as in the case of Fra $i$ due litiganti) noted newly substituted pieces. ${ }^{39}$ Remarkably, Zinzendorf attended and commented on no fewer than twelve of the twenty-eight performances of Fra $i$ due litiganti in its first season. Then and in later years, he frequently compared the work to other operas he had heard, usually expressing his preference for Sarti's opera.

Table 5 illustrates the transformation of Sarti's opera from its original version as performed in Milan to the Viennese version that was widely transmitted throughout Europe in the years after 1783. Column 1 presents the original production in Milan, as documented mostly by the libretto but also by Italian musical sources; two of the numbers in brackets seem never to have been set to music, while the other three were replaced before or shortly after the premiere, but the replacements were almost certainly by Sarti. Column 2 shows the opera as represented in the first Kurzbeck libretto. The new Viennese pieces are in boldface. Column 3 represents the form of the opera as it "settled" following the multiple alternatives tried in the first two months of the Viennese production. As was typical when operas were reworked for productions in other cities, only arias were changed: the ensembles and the final coro of the opera were those written by Sarti, as they were in virtually every production of the work. ${ }^{40}$

\footnotetext{
Alan Brown, was "a sample libretto . . . on paper of inferior quality, probably for proofreading purposes and for submission to the censor": Brown, W. A. Mozart, 22. Apparently, only a single copy of this libretto survives.

37. Link, Arias for Nancy Storace, 113-14, erroneously states that three distinct versions of the Vienna libretto exist; she fully describes them in Link, Arias for Francesco Benucci, 115-16, where her exemplars (a) and (c) are both actually the earlier Vienna libretto and (b) the later one.

38. See Link, National Court Theatre, 194. Link's book contains the most complete transcription of Zinzendorf's diaries, providing all the relevant entries for the years 1783-92 (204-398).

39. See ibid., 195.

40. Both Overture 1 and Overture 2 are associated with the opera in Italian sources; neither represents a new overture used for the first time in Vienna. For a rare example of an ensemble being substituted for an aria—the duet "Là ci darem la mano" from Don Giovanni—see Platoff, "Mozart Duet."
} 


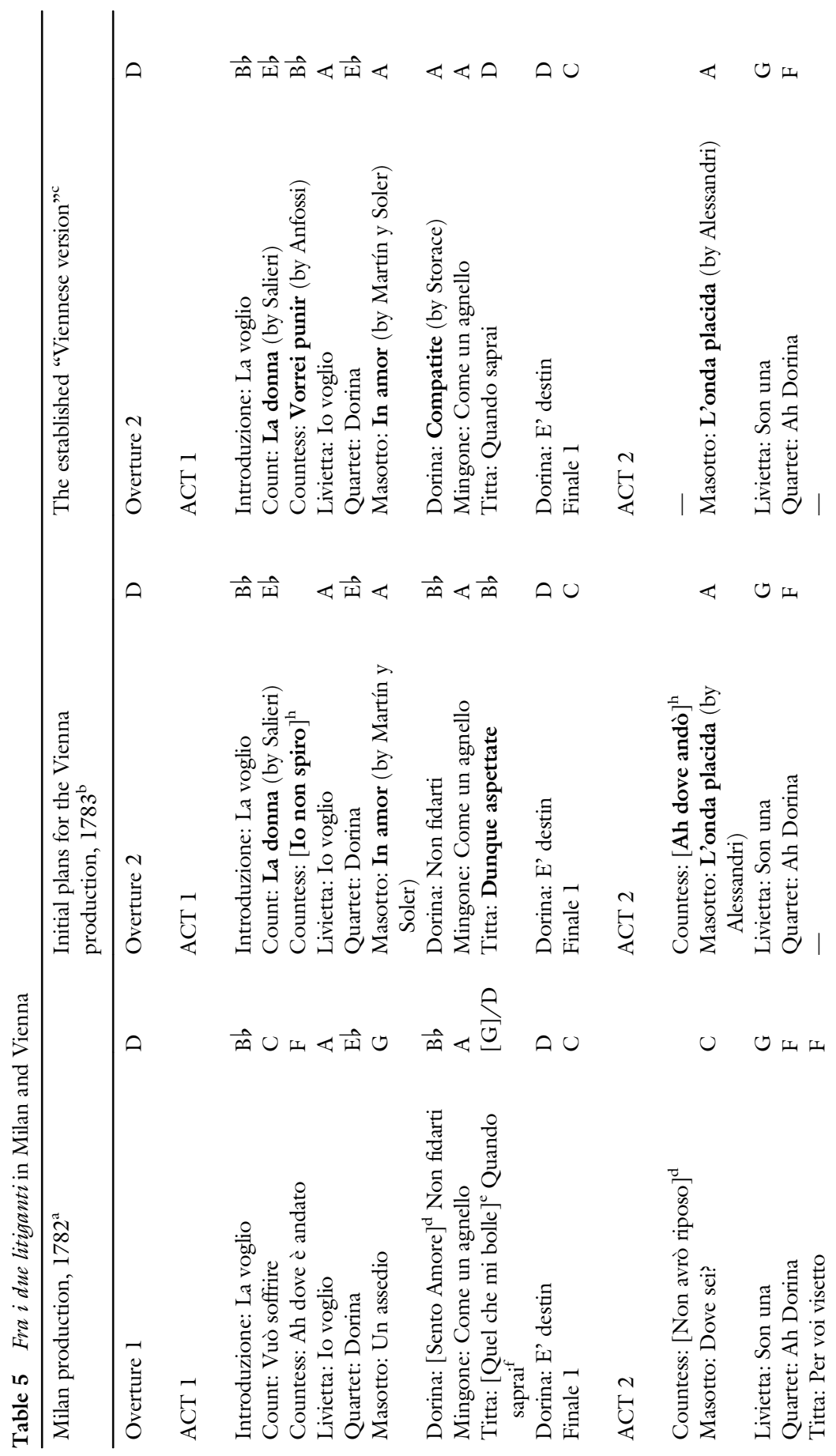

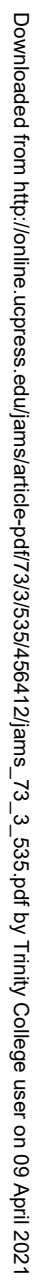




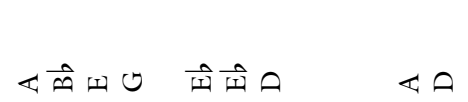

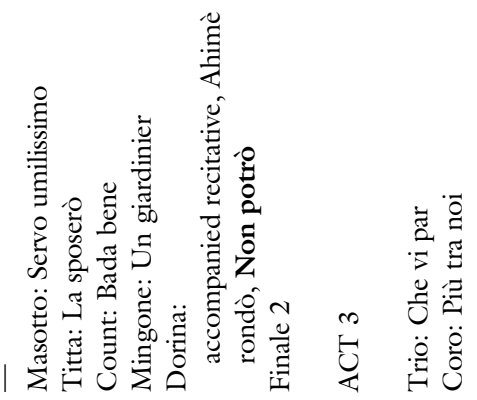

यक्षलण मी

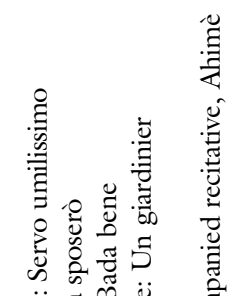

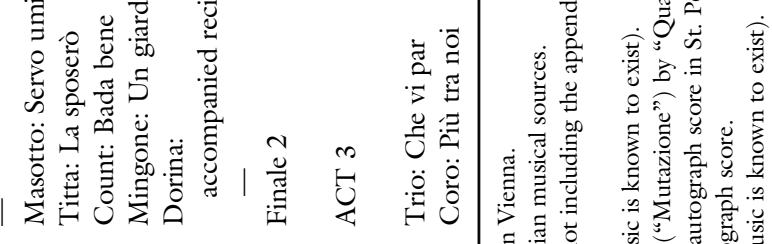

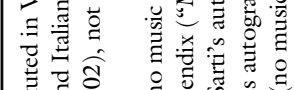

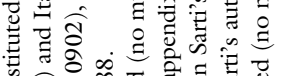

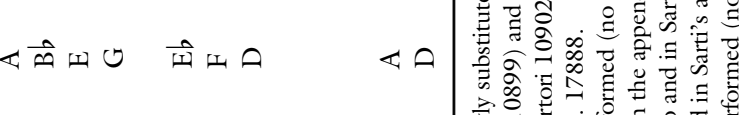

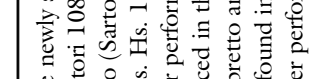

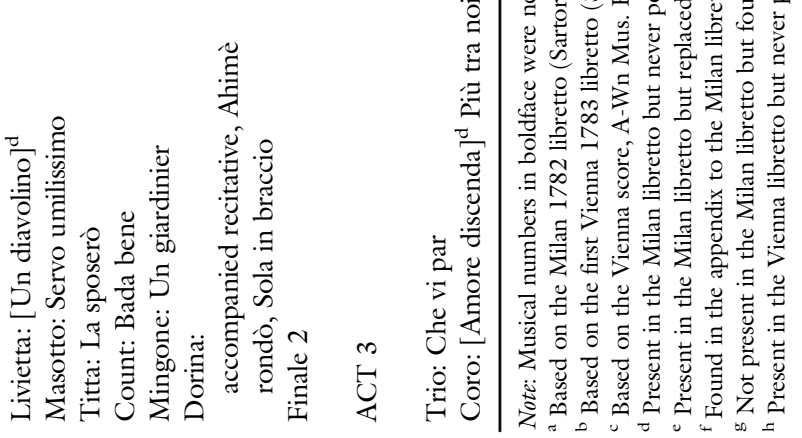

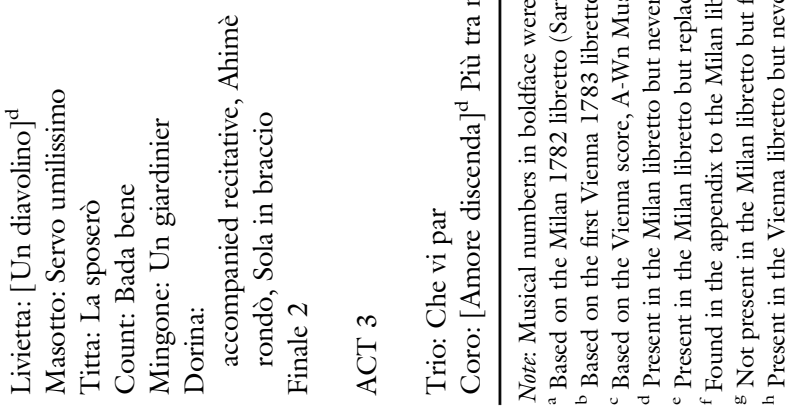

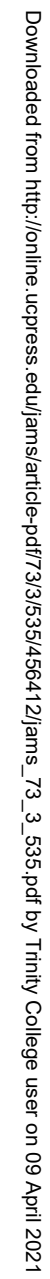


The large number of pieces that were substituted in Vienna is unusual. The vast majority of the productions of the opera that were based on the Milan original - that is, those not derived from the Viennese production-have no more than three substitutions. (The median number in the thirty-three librettos shown in table 2 is two.) Not enough research has yet been undertaken to suggest why so many substitutions were made in Vienna, or even whether this was typical for Viennese productions of imported operas-but there are several possibilities. Salieri, the music director, may have been determined to make his own mark on the new company by thoroughly reshaping the works of others. (Worth noting is the fact that one of the substituted pieces was composed by him, as discussed below.) Or, in the early days of the company, he may have been exceptionally accommodating to the preferences of the singers, providing them with substitutions for any of the arias they regarded as unsuited to their voices. A third possibility is that, since Vienna was a major musical center, there was a larger group of composers ready and willing to supply new arias for an opera than could be found in most other cities. Whatever the reasons, the sources reveal not only extensive changes, but a degree of indecision - or, to put it more positively, a willingness to experiment and to respond to audience preferences.

The first Vienna libretto, almost certainly planned a few weeks prior to the premiere, contains six substitute arias and implies a seventh (Dorina's rondò, for which no text is supplied). These include replacements for two of Sarti's three original arias for Masotto, to be sung in Vienna by Michael Kelly (see table 6), as well as both arias for the Countess (Maria Mandini), and one each for the Count (Franceso Bussani) and Titta (Benucci). A second chronological layer in this libretto is represented by an untitled appendix (p. 134), which contains two aria texts for the Countess to replace those in the body of the libretto, as well as a text for Dorina's act 2 rondò. No music is known to exist for the two arias initially planned for the Countess, "Io non spiro che rabbia e veleno" and "Ah dove andò l'affetto"; indeed, none may have been composed. ${ }^{41}$ The two were then to be replaced by "Vorrei punir l'indegno" and "Dolce d'Amor compagna" respectively: both are found on the appendix page. These latter two are arias by Pasquale Anfossi, from his setting of La finta giardiniera (originally produced in Rome, 1774), which had been performed in Vienna back in $1775 .{ }^{42}$

41. As mentioned above, an aria by Theodor von Schacht on "Io non spiro che rabbia e veleno" exists in the Regensburg library (Fürst Thurn und Taxis Hofbibliothek und Zentralbibliothek, Schacht 134/II; RISM ID 450011080), though it is not part of the Sukowaty score held in that library. The most likely explanation is that Schacht, the house composer for the opera in Regensburg, took the text from the Vienna libretto and, finding no music in the score for "Io non spiro," composed it himself.

42. See Michtner, Das alte Burgtheater, 388, and Hunter, Culture of Opera Buffa, 300. Alterations to the first of these arias (under the slightly modified title "Vorrei punirti indegno") 
Table 6 Singers in the Milan (1782) and Vienna (1783) productions of Fra $i$ due litiganti

\begin{tabular}{lll}
\hline Role & Singer in Milan $^{\mathrm{a}}$ & Singer in Vienna $^{\mathrm{b}}$ \\
\hline Dorina & Nancy Storace & Nancy Storace \\
Titta & Francesco Benucci & Francesco Benucci \\
Masotto & Antonio Palmini & Michael Kelly \\
Mingone & Giuseppe Lolli & Stefano Mandini \\
Livietta & Vittoria Moreschi Bolzani & Therese Teuber \\
Count Belfiore & Giovanni Marliani & Francesco Bussani \\
Countess Belfiore & Angela Marzorati & Maria Mandini \\
\hline
\end{tabular}

a The Milan cast is given in the Milan 1782 libretto (Sartori 10899).

${ }^{\mathrm{b}}$ The Vienna cast names are written in red crayon in the Vienna archival score, A-Wn Mus. Hs. 17888. The first five names (i.e., all but the Count and Countess) are confirmed by Zinzendorf's diary entry for the first performance; see Link, National Court Theatre, 205-6.

At the point in the Vienna libretto where Dorina's rondò should appear, following her extended accompanied recitative (just before the act 2 finale, the most common place for the prima donna's rondò), ${ }^{43}$ there is no aria at all, but the appendix supplies a rondò text, "Quando mai del mio tesoro." In this case, too, no music is known to exist, and the aria may never have been performed. This combination of facts makes clear that, even as late as a few days before the premiere, Dorina's rondò had not been decided on. ${ }^{44}$ It is clear that the appendix was added at a late stage to the already-prepared libretto-but in all probability before printing began, since no exemplars are known to exist without it. Since the libretto would have needed to be available for sale by the time of the May 28 premiere, it is reasonable to assume that it was printed just before that date. Time must have been short: unlike the rest of the libretto, the appendix page is not accompanied by a German translation on the facing page.

A copy of the first Vienna libretto that is now in Rome contains handwritten insertions for three arias: Dorina's act 1 "Non fidarti Amor mi dice" (discussed below); her act 2 rondò for which the original printed libretto contains no text (see above); and the Countess's "Ah dove andò l'affetto," which, as discussed above, was never set to music and was replaced by an aria by Anfossi. According to John Rice, these insertions are in the hand of Lorenzo Da Ponte. ${ }^{45}$ While none of Da Ponte's texts appears to have been used, their presence confirms that as the company's librettist he would have been

in a variety of sources, including the Eszterháza score, are discussed in Siegert, "Rezeption durch Modifikation," 112-23.

43. See Platoff, "How Original Was Mozart?," 106.

44. One possibility is that a setting of "Quando mai" was commissioned and composed but then rejected, by which time it was too late to make any further changes to the libretto.

45. Rice, "Libretto Collection," 434-38 (reproductions of the pages containing Da Ponte's new texts are given as figures 26.1-3). The libretto is in the Carvalhaes Collection in the Accademia Nazionale di Santa Cecilia. 
directly involved in the process of providing substitute arias as needed for operas imported from other cities.

Column 3 of table 5 shows the settled Viennese version of the opera which had been arrived at by the end of July, and which is reflected in the score now numbered 17888. It represents the third chronological stage of the opera's alteration in Vienna, including the several changes made after its Viennese premiere and in the first few weeks of its successful run. Four of the substituted arias initially chosen for the new production remained in this version (those for Masotto and the Count, and the Countess's "Vorrei punir," which was in the appendix to the first Vienna libretto). But there were four additional changes: the Countess's aria "Dolce d'Amor" was cut; new substitute arias were supplied for Dorina and Titta (I discuss both of these below); and a rondò, "Non potrò del caro bene," was finally decided upon for Dorina. The final tally of non-Milanese arias in the Viennese version is six. ${ }^{46}$ The composers of five of these arias can be identified. ${ }^{47}$ Composers' names for four of them appear in the Budapest score copied by the Sukowaty firm: "La donna e sempre instabile" is by Salieri; the previously mentioned aria for the Countess is by Anfossi, from his La finta giardiniera; "In amor ci vuol finezza" is by Vicente Martín y Soler; ${ }^{48}$ and Dorina's "Compatite miei signori" is by Stephen Storace, the young English composer who was the older brother of Nancy Storace, the soprano who sang the role. ${ }^{49}$ The composer of Masotto's "L'onda placida e tranquilla" in act 2 is not named in the Budapest score, but the piece has been identified by Roland Pfeiffer as an aria by Felice Alessandri from his La finta principessa (Venice, 1782) ${ }^{50}$

46. While the total would appear to be seven, Titta's substitute aria "Quando saprai" actually represents the readoption of an aria written by Sarti for Milan, as I discuss below.

47. Pfeiffer, Opere buffe, 53n122, points out that Hunter, Culture of Opera Buffa, 148ff., erroneously treats several of the substituted arias as being by Sarti. The mistake is quite understandable, however, since the Viennese archival score and both Viennese librettos present the arias without attribution. Identification of the composers of substituted arias in librettos, as in the case of Mozart's arias for Aloysia Lange in a performance of Anfossi's Il curioso indiscreto in Vienna in 1783 , is extremely rare.

48. See Waisman and Romagnoli, Vicente Martín y Soler, 217. It appears to be a lightly altered version of the aria "In amor ci vuol malizia," sung by the character Zolfanello in Martín's In amor ci vuol destrezza, which premiered in Venice in 1782.

49. Bartha and Somfai, Haydn als Opernkapellmeister, 278-79, notes only three of the composers' names and does not mention Salieri, though his name is plainly visible on the aria in question. There is independent confirmation of Salieri's authorship in an autograph score of the aria in Vienna (see Pfeiffer, Opere buffe, 53n122), and of Anfossi's aria in manuscripts of La finta giardiniera. Martín y Soler is also named as the author of "In amor ci vuol finezza" in KT 357 (as "Martini"). No independent corroboration exists for the Storace attribution, but it stems from a Sukowaty copy and there seems no reason to doubt it.

50. Pfeiffer, Opere buffe, 53nl22. According to Edge, "Mozart's Viennese Copyists," 2194, the score of La finta principessa was probably one of a group of scores sent back to Vienna from Venice by Count Durazzo, like the score of Fra $i$ due litiganti now cataloged as 
As a whole, the changes made in Vienna reflect greater concern for some roles, or some singers, than for others. The roles of the secondary characters Livietta and Mingone remained unchanged from the Milanese version. One of the two arias for Bussani as the Count was newly written by Salieri. Maria Mandini as the Countess - also a secondary role—was initially to have two new arias. However, these were replaced by two existing Anfossi pieces from an earlier opera, and in the end one of these was dropped, leaving her with just a single aria. The singers playing the leading roles of Dorina, Titta, and Masotto received more attention. As mentioned above, two of Masotto's arias were new to the Viennese version of the opera. Probably, these were chosen by the singer Kelly, or at least with him in mind.

\section{A Case Study: Nancy Storace and Her Viennese Operatic Persona}

The changes made to the roles of Dorina and Titta are the most surprising, since Storace and Benucci had already sung them in the initial Milanese production (as shown in table 6). We think of substitute arias as pieces requested or demanded by singers to match their vocal and dramatic strengths more closely than the original arias. In this case, since Storace and Benucci had created the roles of Dorina and Titta, the usual explanation would seem not to apply. But whatever the reasons, the changes resulted in a reshaping of the singers' roles in the opera, in a way that-above all in the case of Storace-helped to create their operatic personae for Viennese audiences, not only in this opera but more generally. The ways in which the revised role played to Storace's strengths have particular significance because Storace's Dorina, as the role was reshaped in Vienna, bears such a striking resemblance to her Susanna in Mozart's Le nozze di Figaro of only three years later.

Storace's early life and career indicate that, even by the standards of the eighteenth century, when singers began performing professionally at earlier ages than today, she was something of a prodigy. Born in 1765 in London, the daughter of an Italian musician, she studied there with the castrato Vincenzo Rauzzini. By the time she was fourteen, Storace was already singing in Florence, Lucca, Turin, and other Italian cities, where-despite her training with Rauzzini-she sang only a few roles in opere serie, mostly performing prima buffa and prima seria roles in opere buffe. ${ }^{51}$ In 1782 she triumphed in Milan as Dorina in Fra $i$ due litiganti, the first leading role written

KT 357. The sixth substitute aria in A-Wn 17888, Dorina's rondò "Non potrò del caro bene," is possibly by Cimarosa, as suggested by Pfeiffer, Opere buffe, $53 \mathrm{nl} 22$.

51. See Rice, Antonio Salieri, 335, and Gidwitz, "Vocal Profiles," 106-8. 
expressly for her. She was still only sixteen. After that success, she sang three leading roles in Venice during the 1783 Carnival season, where she was greeted with rapturous applause. There, Count Durazzo heard Storace perform and recommended her for Joseph II's new Viennese opera buffa company. ${ }^{52}$ In Vienna as in Italy, she undertook both prima buffa and prima seria parts. Her first Viennese role was among the latter: the Countess in Salieri's La scuola de' gelosi, which Durazzo had just heard her sing in Venice. This was followed by a buffa role in Cimarosa's L'italiana in Londra, and then her brilliant success as Dorina. Storace went on to sing for four years as the most highly paid member of the Viennese company. ${ }^{53}$ She performed some twenty operatic roles at the Burgtheater, many of them written expressly for her.

Forming a clear picture of Storace as a singer is not an easy task, primarily because the written judgments that have come down to us are so widely varied and stem from very different stages in her career (which continued until 1808). Some commentators praised her vocal agility and brilliance, and there are multiple reports of her having mimicked to perfection the virtuosic improvisations of the famous castrato Luigi Marchesi during and after his performances in Vienna in $1785 .{ }^{54}$ On the other hand, many listeners (especially later in her career) complained of vocal limitations, especially with respect to her agility and purity of tone. Patricia Lewy Gidwitz, who studied in detail Storace's voice and some of the music composed for her, reports that "from the extensive cuts and transpositions in the music for the Countess [in Salieri's La scuola de' gelosi], we learn that Storace was not entirely comfortable with the vigorous display of agility which normally accompanies the expression of exalted passions." 55 More generally, Gidwitz asserts that music written for Storace tended to lie somewhat lower in the soprano range and feature fewer bravura high notes or passages of extended coloratura. Link, who has also studied Storace's music and published an anthology of arias associated with her career, concludes from the wealth of contemporary reports that "Storace had the technique for the seria style, but not the voice." 56

But if Storace the singer is somewhat hard to bring into focus, Storace the actress is not: she was universally acclaimed for her brilliant dramatic talents, as well as (in the early years) her attractiveness. Contemporary observers remarked that she had an appealing figure and enormous charm on stage; as Isabelle Emerson puts it, "her genius lay in acting in music,

52. See Gidwitz, "Vocal Profiles," 108.

53. See Link, National Court Theatre, 408-9, 412, 415-16, 421. In some years Storace's salary is matched, though never exceeded, by that of one or two other singers.

54. See Link, Arias for Nancy Storace, viii, xi.

55. Gidwitz, "Vocal Profiles," 126.

56. Link, Arias for Nancy Storace, ix. 
particularly in comic or witty roles, and ... she was extraordinarily capable of communicating the dramatic sense of the music." ${ }^{57}$ Storace was a particular favorite of Count Zinzendorf, who commented far more frequently on her acting and her physical attractiveness than on her singing. It is striking how often he praised her performance in comic ensembles, which generally provide more opportunity for displaying one's acting talents. ${ }^{58}$

In the playful act 3 trio of Fra $i$ due litiganti, "Che vi par Dorina bella," Dorina pretends to respond to Titta's attentions while she and Masotto flirt amusingly behind Titta's back. This trio was among the opera's most popular numbers - it was one of the "Favorite Songs" from the opera to be included in a 1785 London publication, ${ }^{59}$ and it was frequently moved into act 2 when the opera was presented in a two-act version, which occurred in many productions (above all in Italy). Zinzendorf was enchanted with the trio, mentioning it no fewer than five times in the first two months of the opera's performances - the most he refers in his diary to any single operatic number. ${ }^{60}$

The key moment in the trio comes when Dorina agrees to Titta's request to let her "husband" kiss her hand. While giving one hand to Titta-who thinks he is to be the husband-she invites Masotto to kiss her other hand behind Titta's back. When Titta tries to kiss the hand again, she tells him, "but not so strongly [ si forte]," while urging Masotto to kiss again, "fortissimo." No fewer than three of Zinzendorf's comments on the trio refer to this passage. It is typical of the kind of comic byplay at which Storace excelled, and which is equally prominent in many moments of Figaro, from Susanna's mocking emergence from the closet in the act 2 finale, to her "yes-no" duet with the Count in act 3 .

The broad trajectory of Storace's four-year career in Vienna was a gradual move away from parti serie, with their grand, formal solos full of virtuosity, toward parti buffe, in which the vocal demands were more modest and her dramatic talents could be put to best use. Gidwitz makes the point that this adjustment came in part as a response to "the local talent poolwith [Aloysia] Lange and [Caterina] Cavalieri chief among her rivals." We have already noted that Salieri apparently adjusted the music for Storace as the Countess in La scuola de' gelosi in order to reduce its vocal demands. In Fra $i$ due litiganti, an even more significant change was made to Storace's role as Dorina.

57. Emerson, Five Centuries, 100.

58. See Link, National Court Theatre, 204-7, 211.

59. Favorite Songs.

60. Zinzendorf reports that at the performance of the opera on July 9, 1783, the trio was performed three times (that is, encored twice); and that at the performance on July 16, the emperor was very pleased ("fort content") with the trio; Link, National Court Theatre, 207-8.

61. Gidwitz, “'Ich bin die erste Sängerin,'” 576n19. 
Dorina sings three solo numbers in addition to a short solo section in the act 1 finale. In Sarti's Milan version, all three are more serious or sentimental than comic in character. And two of them-Dorina's first aria, "Non fidarti Amor mi dice," and her rondò in the second act, "Sola in braccio al mio periglio"-involve music of a distinctly grand style, more suited to a parte seria than a prima buffa, especially one playing a chambermaid. "Non fidarti" in particular seems strikingly inappropriate for the dramatic situation in which it appears, at least by modern standards. It is Dorina's first musical number, and it occurs at the climax of a scene in which she is being relentlessly and comically pressured by the two hapless suitors Titta and Mingone to choose between them. Having been quietly apprised by Masotto of his own interest in her, Dorina wishes to fend them off. The comedy of the situation, however, is abruptly halted by her aria:

Non fidarti Amor mi dice Del linguaggio degli amanti, Con lamenti, smanie e pianti Sono avvezzi ad ingannar.

$5 \quad$ Che vi par di questo avviso State li, più non parlate. Ah mi fate un certo viso Che m'insegna a dubitar.
Do not trust, Love tells me, The language of lovers; They are used to deceiving With laments, rages, and tears.

What do you think of this advice? Stay there, say nothing more. Ah, you look at me in a way That leads me to doubt. ${ }^{62}$

Especially in the first quatrain, the text abounds in language from the world of opera seria: "lamenti, smanie e pianti," for instance. And its representation of Dorina's situation is abstract and formal, as though she is lecturing her suitors on the philosophy of courtship.

Musically, too, everything about "Non fidarti" suggests grandeur and formality. Dorina's vocal entry, shown in example la, follows a two-minute orchestral introduction in Trommelbass style with an elaborate solo for obbligato clarinet. It features a decisive triadic opening gesture followed by a long held note beneath the clarinet melody. Later in the aria there are multiple passages of extensive coloratura in dialogue with the clarinet (one of them given in example lb). ${ }^{63}$ All in all, "Non fidarti" is a bravura showpiece, and it evokes an aristocratic, opera seria world far removed from that of a chambermaid.

62. The Italian text is taken from the first Vienna libretto (Sartori 10902); the translation is mine.

63. Examples $\mathrm{la}$ and $\mathrm{lb}$ are reduced from the Dresden score D-Dl Mus. 3273-F-503. 
Example la Sarti, "Non fidarti Amor mi dice," mm. 40-49
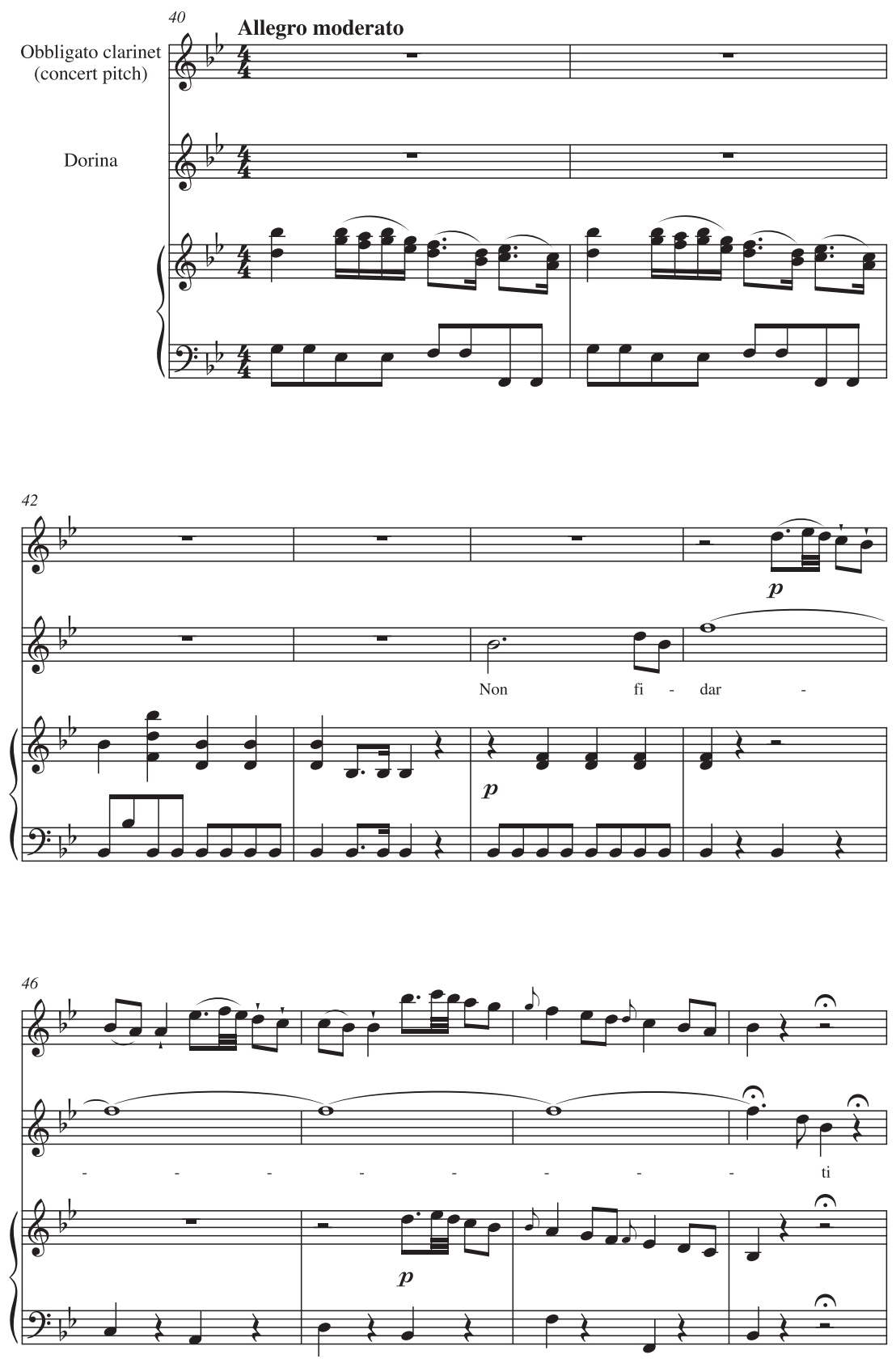
Example 1b Sarti, "Non fidarti Amor mi dice," mm. 69-82
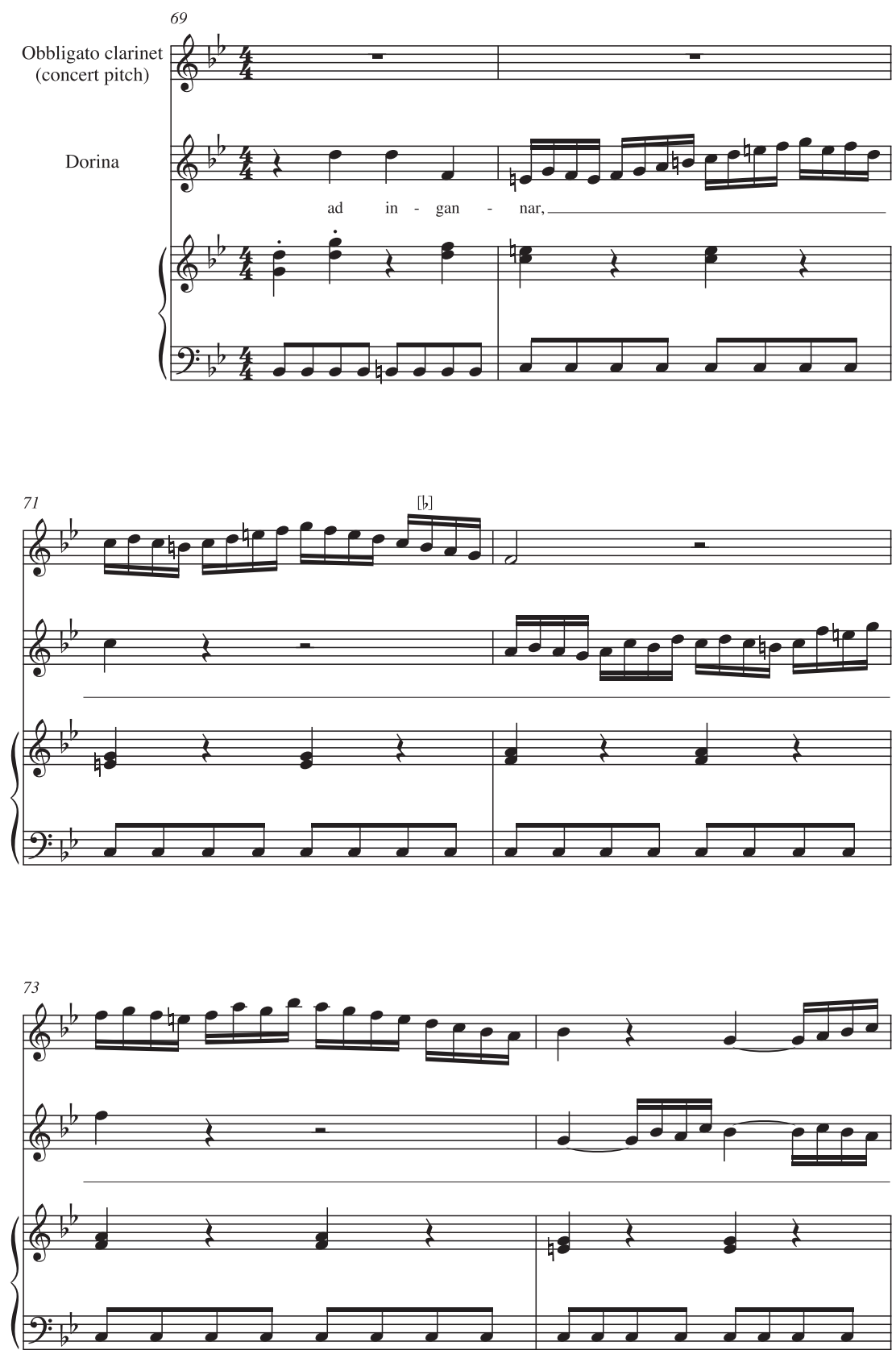
Example 1b continued
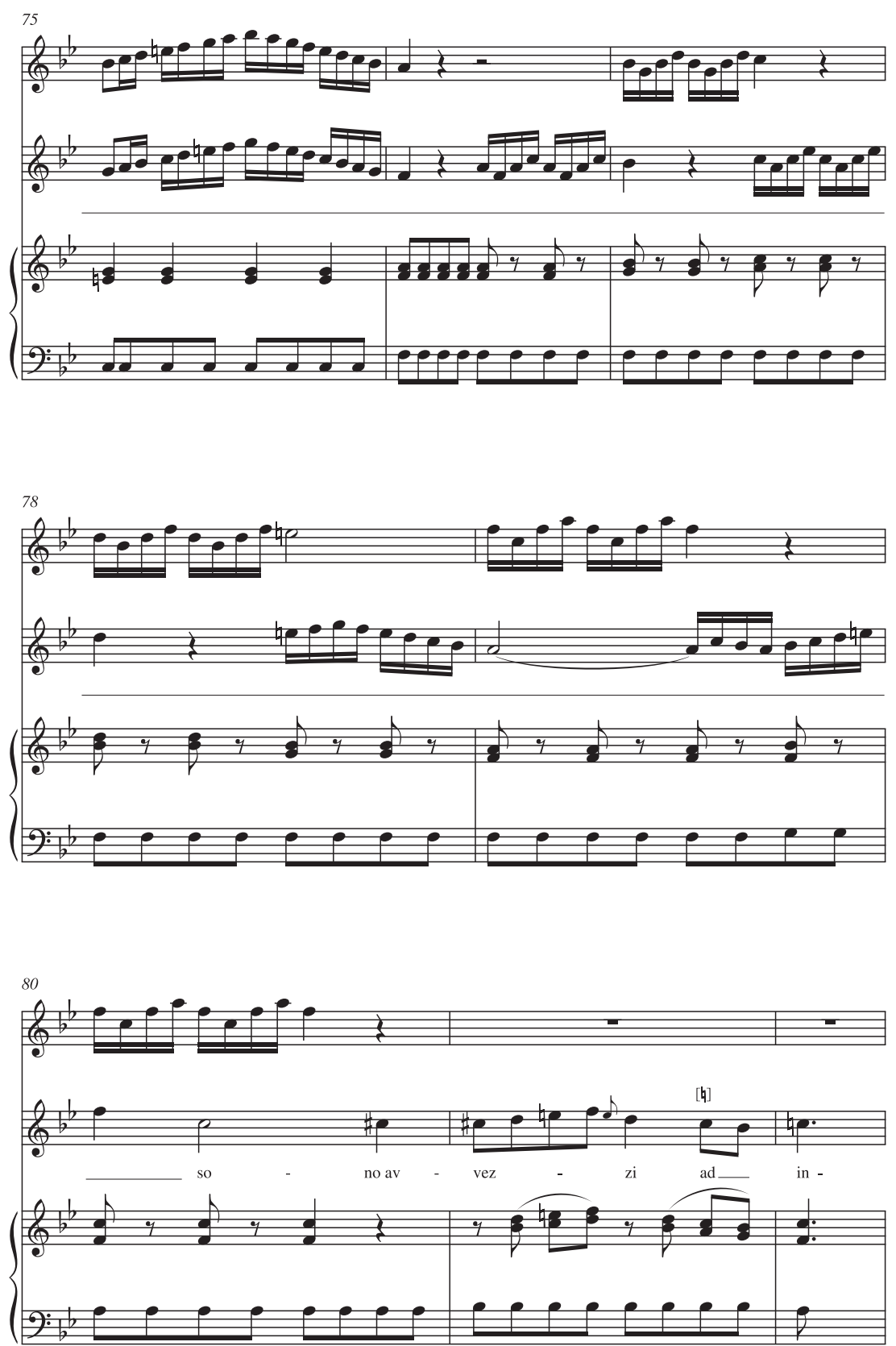
Early in the Viennese run of Fra $i$ due litiganti, however, Storace replaced the aria with a completely different piece, written by her brother Stephen. Unlike "Non fidarti," the new aria, "Compatite miei signori," beautifully fits both the situation and the singer's strengths:

Compatite miei signori

Se vi deggio qui lasciar.

(Un si storce, l'altro freme, Ma gli voglio far crepar.)

5

Tornerò si m'attendete Ma signori che cosa avete? Quella faccia così mesta, Deh non state a dimostrar.

9

Già sapete $o$ giovinotti Che l'amor è una pazzia; Voi si fiera malattia Procurate di sanar.

13 Maladetta la mia prescia Ma non posso qui restar.
Pardon me, gentlemen, If I must leave you here.

(One writhes, the other trembles, I'd like to make them both croak.)

I'll return if you'll wait for me-

But gentlemen, what's the matter?

Please don't show me

Such sad faces.

You already know, young men, That love is a madness;

You should try to cure yourselves

Of such a grave illness.

Damn my haste

But I can't stay here any longer. ${ }^{64}$

The aria is an Andantino with a light, grazioso vocal line, well matched to the teasing, flirtatious tone of the text. In the opening vocal section, shown in example 2, Dorina's phrases are simple, largely syllabic, and at times even declamatory (as in mm. 24-29). ${ }^{65}$ One can see in the poetry-which is quite down-to-earth in style and language - that Dorina alternates between behaving politely to her suitors, making fun of them in an aside, and then-in a slightly faster Allegro that begins at line 9-mock-seriously advising them to seek a cure for the disease of love that is plaguing them. "Compatite" thus suits both the character of Dorina and her situation better than "Non fidarti." It is the type of piece that Susanna might sing in Figaro, perhaps as she tries to fend off the advances of the Count. And it beautifully plays to Storace's strengths as a playful, charming actress rather than a brilliant virtuoso singer-strengths that increasingly came into focus in her Viennese roles, up to and very much including that of Susanna. ${ }^{66}$

The exact timing of the substitution can be dated within approximately six weeks in the summer of 1783 . Storace certainly sang "Non fidarti" in the initial performances of the opera: the aria's text appears in both versions of Kurzbeck's libretto, and it is named specifically by Zinzendorf in

64. The Italian text is taken from the score A-Wn 17888; the translation is modified from Link, Arias for Nancy Storace, xix. As Link indicates (114), lines 9-12 were altered slightly in the course of the production; the text presented here is the latest version.

65. Example 2 is reduced from the score A-Wn 17888.

66. A complete piano-vocal score of the aria is given in Link, Arias for Nancy Storace, 20-26. 
Example 2 Stephen Storace, “Compatite miei signori,” mm. 12-29
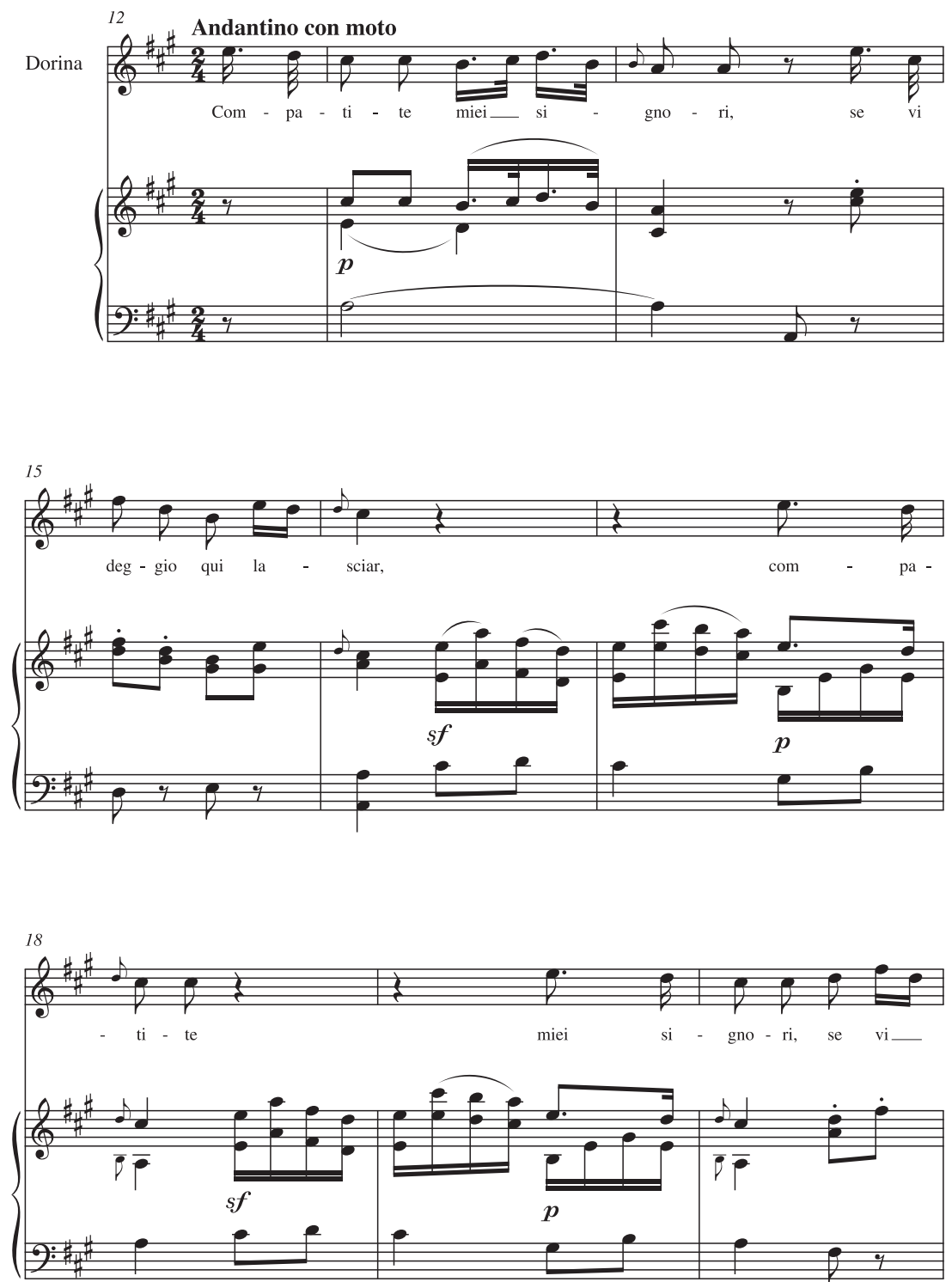

(continued)

his comments about the opera's opening night. Link believes that Storace began singing "Compatite" no later than the performance of June 11, relying on a somewhat ambiguous comment by Zinzendorf. ${ }^{67}$ In any case, the new

67. Ibid., 115 and $n 7$. Zinzendorf's comment of June 11 is that the opera "still enchanted me, especially in the first act the finale, which is superb, [and] an aria sung by Storace at the end 
Example 2 continued
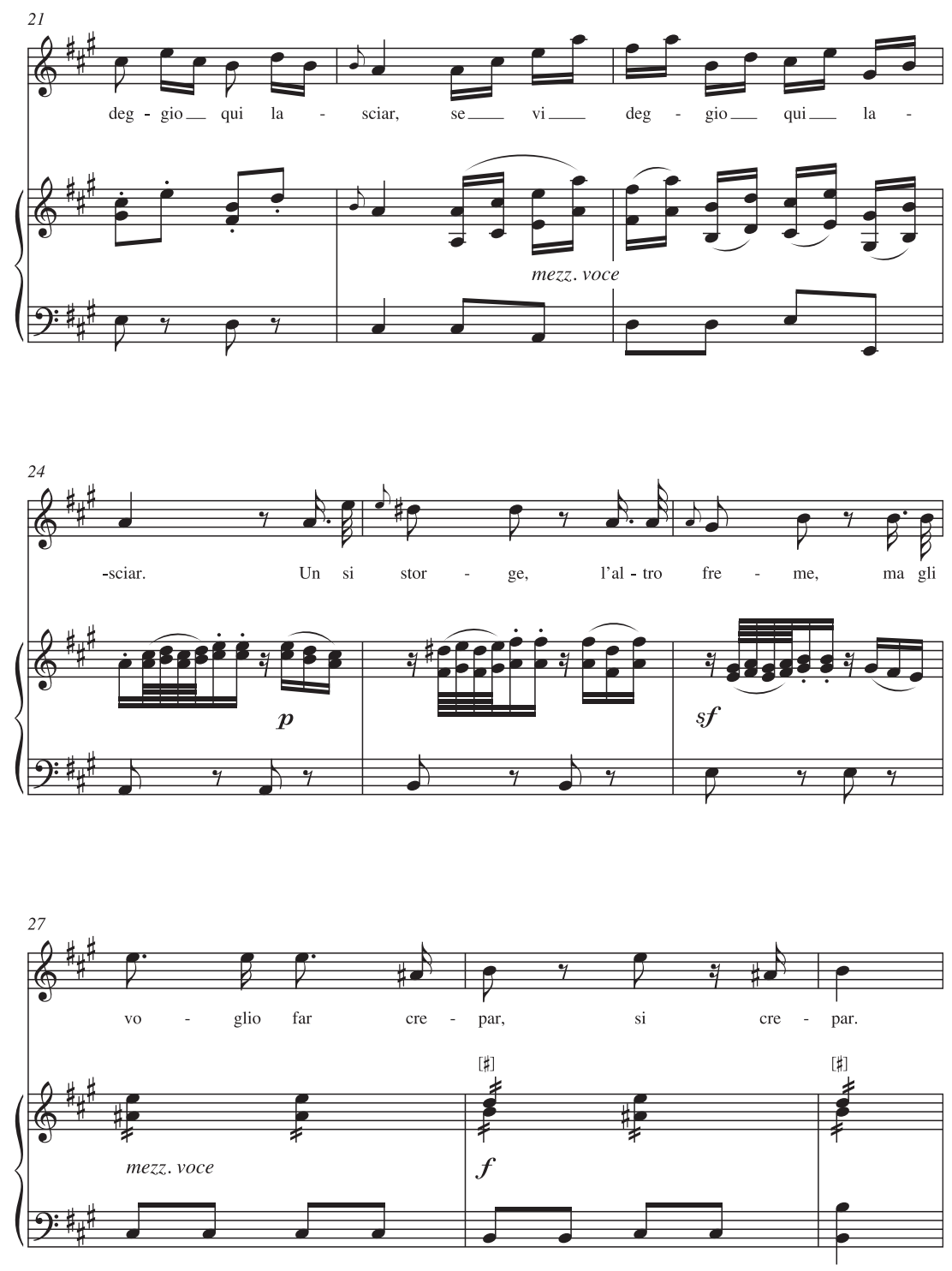

of the sixth scene" ("Il m'enchanta encore, surtout dans le Ier acte le final qui est superbe, un air que la Storace chanta a la fin de la 6me Scene"). Link interprets this remark as referring to a new aria, but that is not entirely clear. Moreover, Zinzendorf's comment about the July 9 performance, that "Miei signori, cosa fu really struck me this time" ("Miei signori, cosa fû me frappe beaucoup cette fois cy"), refers not to "Compatite," as Link claims, but to a passage in the finale to act 1 (ibid., 115 and $n 8$ ). 
aria had certainly replaced "Non fidarti" by early July, since "Compatite" appears in the score copied by Sukowaty for Eszterháza, which had to have been produced by that time.

There are multiple reasons why Storace might have wanted to replace "Non fidarti" with "Compatite." One obvious reason is the desire to give her brother an opportunity to impress Viennese audiences (and perhaps the emperor) with his abilities as a composer. (And indeed, Stephen was commissioned in 1785 and 1786 to write two opere buffe for the Viennese company.) But a prime motivation was surely the desire to succeed to the greatest extent in winning the approval of Viennese operatic audiences. As Zinzendorf's comments make clear, Storace's acting and her talent for comic byplay were highly prized. It seems likely that her decision to replace "Non fidarti" with a number that highlighted her comic, flirtatious side represented a conscious effort to present herself as less of a virtuoso seria singer and more of a charming comic presence. ${ }^{68}$ In so doing, she altered both the way she was seen by Viennese audiences and the way Dorina was understood. In both respects, she paved the way for the creation of Da Ponte and Mozart's Susanna.

\section{A Case Study: Francesco Benucci and "Quando saprai chi sono"}

The case of Benucci's act $\mathrm{l}$ aria is the opposite of Storace's. While she began the Viennese run of Fra $i$ due litiganti with the aria she had successfully sung in Milan only to replace it with a new piece, Benucci began in Vienna with a new substitute aria but dropped it after just a few weeks, returning to Sarti's Milanese original. Yet the situation is even more complicated, because, as the Milan libretto of Fra $i$ due litiganti makes clear, Sarti wrote two entirely different versions of Titta's act 1 aria for Benucci (see table 5). The first version, "Quel che mi bolle in testa," must have been replaced shortly before the premiere by "Quando saprai chi sono," since the former appears in act 1 , scene 9, of the Milan libretto, while the latter is in an appendix (labeled "Mutazione," or "Substitution") on the libretto's final two pages. Interestingly, both of Sarti's arias circulated widely in sources based on the Milan version. "Quel che mi bolle" appears in more than a dozen librettos, including some as late as the early 1790s, and in several Italian scores. "Quando saprai" is found in Sarti's autograph and in numerous Italian librettos and scores, as well as in virtually all the sources based on the opera's Viennese version.

"Quel che mi bolle," which in all likelihood was never performed in Milan, presents Titta in an amusing if not entirely original situation: his

68. Of course, this change affected only one of Storace's three arias. The other two, and especially the rondò, still required singing in the grander seria style. 
attempts to woo Livietta (the maid who is his second choice, should his pursuit of Dorina not succeed) are repeatedly interrupted by the ringing of a bell summoning him to serve the Count. The humor is provided by Titta's back-and-forth addresses to Livietta and to his absent master, along the lines of "Ah, my dear one-yes sir, I'm coming!" The final section of the aria explodes into rapid patter, the poetic lines switching from settenari to quinari doppi (that is, from seven-syllable lines to lines consisting of two five-syllable halves), as Titta vents his frustration with the ceaseless ringing of the bell. All in all, this is an effective buffa aria, very familiar in its overall form, style, and rhetorical strategies. ${ }^{69}$

"Quando saprai" is far more ambitious, however: it is an elaborate multitempo piece that gives Titta the opportunity to present himself as former servant to a knight or swordsman, ${ }^{70}$ a dancer, and a singer:

Quando saprai chi sono

Sì fiera non sarai,

Nè parlerai così.

Un servitor sì buono

$5 \quad$ Nel mondo non fu mai,

Nè trovasi oggidì.

Ho servito un Paladino,

Che ogni giorno col passetto

Perchè ho forte, e duro il petto

10 Mille botte mi tirò.

Una ricca ballerina

Poi mi prese per lacchè,

E il mio merto in anni tre

Cento Scudi guadagnò.

15 Con un musico soprano

Fino in Londra son andato, E la musica ho imparato.

Non credete? Or canterò.

Mia speranza io pur vorrei

E dar fine ai mali miei

Coronando la mia fè;

Dite voi se in tanto affanno

Io no merito pietà.

When you know who I am, you won't be so proud nor speak like that.

Such a good servant was never seen on earth before nor is to be found today.

I have served a knight, who every day gave me a thousand blows with his rapier because I have a strong, hard chest.

Then a rich dancer took me on as a lackey, and in three years my merits earned me a hundred scudi.

With a soprano castrato I went as far as London, and I learned music.

You don't believe me? I will sing.

My hope, I would like to languish here at your dear feet; and put an end to my pains, crowning my faith.

Say whether I don't deserve pity in so much anguish. 
Ma questo è ancor pochissimo

Per tanta abilità.

Sono un diluvio un fulmine

Di grazia, e di beltà;

Voi belle donne, ditelo,

30

Se questa è verità.
But this is still too little for so much ability. I am a deluge, a thunderbolt of grace and beauty. You, beautiful ladies, say if this is not true. ${ }^{71}$

Significantly, the aria was also designed to appeal to the Milan audience by directly quoting one of Sarti's most famous opera seria arias, the rondò "Mia speranza io pur vorrei” for Achilles from Sarti's Achille in Sciro (Florence, 1779). The celebrated castrato Luigi Marchesi, a Milan native, had performed the aria to great acclaim in the city when he inserted it into Mysliveček's Armida during the Carnival season of 1779-80. ${ }^{72}$ In "Quando saprai," Benucci as Titta quotes not only the main theme of the Largo of the rondò (text lines 19-22), but also the main theme from its Allegro section, "Dite voi" (lines 23-24). Except for a change of key from A (in the original aria) to $\mathrm{G}$, the passages are quoted exactly; audiences in Milan would have had no difficulty in recognizing, and being amused by, Titta's comic appropriation of the ardent music from Marchesi's rondò. ${ }^{73}$

Strikingly, "Quando saprai" opens with a reference to yet another opera seria aria by Sarti, though its music would not have been known to the Milan audience of 1782. The first three lines of text stem from an aria for Aeneas in Metastasio's renowned libretto La Didone abbandonata, originally from 1724 and set to music more than sixty times by the early nineteenth century. And, according to Pfeiffer, Titta's music for these lines is virtually identical to Aeneas's music in Sarti's setting of Didone for Padua in June 1782, only a few months before the premiere of Fra $i$ due litiganti. ${ }^{74}$ While the audience could not have known that Titta was quoting Aeneas's music from Sarti's recent setting of the opera seria, some operagoers might have recognized the familiar lines from Metastasio's famous libretto and been amused at Titta's presentation of himself as the great hero of classical tragedy-followed later in the aria by his presentation of himself as Achilles.

71. The Italian text is taken from the Milan 1782 libretto (Sartori 10899); the translation is modified from Link, Arias for Francesco Benucci, xx-xxi.

72. This aria is discussed in Rice, "Sense, Sensibility," 119-24, and Nahon, "Le origini del rondò," 56-61. Rice cites contemporary sources attesting to the enthusiasm with which Marchesi's performance was received. The quotation of "Mia speranza" in "Quando saprai" was first noted in Pfeiffer, Opere buffe, 141-43.

73. The passages are given as examples 1 and 3 in Rice, "Sense, Sensibility"; the Largo theme is also in Pfeiffer, Opere buffe, example 9. The entire aria appears in piano-vocal reduction in Nahon, "Le origini del rondò," appendix 5.

74. Pfeiffer, Opere buffe, 51-52 and nl17. 
For the Vienna production, Benucci was provided with a new substitute number, "Dunque aspettate o cara," ${ }^{75}$ perhaps because the references in "Quando saprai" to Marchesi's famous aria would be lost on the Viennese audience. (Marchesi did not sing in Vienna until 1785, when he appeared to great acclaim in Sarti's Giulio Sabino.) "Dunque aspettate" appears in the earlier Viennese libretto as well as in the Sukowaty score copied for Eszterháza, and it was also mentioned by Zinzendorf as one of the numbers performed in the opera's Vienna premiere. ${ }^{76}$ It has the form and style of a standard buffa aria, the conceit being that Titta, while ostensibly wooing Livietta, reflects to himself on the negative aspects of matrimony, above all its financial burdens. It is a typical buffa piece, but far from inspired. In particular the final patter section, in which Titta lists in catalog fashion the bonnets, the ribbons, the feathers, and so on that a wife will need, is remarkably pedestrian.

Perhaps not surprisingly, it was not very long into the Viennese run of Fra $i$ due litiganti that Benucci dropped "Dunque aspettate," returning with apparent success to "Quando saprai." Zinzendorf comments on the latter aria in his diary entry for July 21, 1783: "Benucci sang a big aria in which he played a swordsman, a dancer, and a [castrato] soprano." ${ }^{77}$ But unlike that in Milan, the aria's success in Vienna cannot have rested on its comic reuse of Marchesi's rondò. The logical conclusion is rather that "Quando saprai" allowed Benucci to show the full range of his singing and acting abilities, in a piece in which he could portray multiple characters and moods. ${ }^{78}$

Benucci was in fact known to be a remarkable comic actor, as a number of commentators testified. The Berlinische musikalische Zeitung provided the most detailed account in 1793, citing his "unaffected, excellent acting" and adding "he never exaggerates. Even when he brings his acting to the highest extremes, he maintains propriety and secure limits, which hold him back from absurd, vulgar comedy." "79 Joseph II himself praised the way in which, as Dr. Bartolo in Paisiello's Il barbiere di Siviglia later in 1783, Benucci copied the German actor Friedrich Ludwig Schröder, who played Bartolo in the spoken drama, "almost to the hair." ${ }^{80}$ And on more than one occasion, the emperor indicated that he regarded Benucci (who sang in Vienna nearly every

75. This is the aria's title in the Vienna libretto; in several scores it begins "Dunque ascoltate o cara." I have found no information as to who might have composed it, though it is a reasonable assumption that the text is by Da Ponte.

76. See Link, National Court Theatre, 206.

77. Ibid., 208: "Benucci chanta un grand air ou il fut le Spadassin, le loureur et le Soprano" (my translation). In both the two Vienna librettos and the St. Petersburg autograph score (RUSSPtob 467), line 7 contains the word "paladino" (knight). But in the manuscript pianovocal score that Link uses for her edition of the aria (Vienna, Österreichische Nationalbibliothek, Musiksammlung, Suppl Mus 10080) the word is replaced by "spadacino" (swordsman): Link, Arias for Francesco Benucci, 27-37, 115. French and German translations of the opera (based on the Vienna version) also refer to a swordsman rather than a knight.

78. These points are also made by Link, Arias for Francesco Benucci, xi-xii.

79. Quoted in Link, Arias for Francesco Benucci, viii (emphasis in source).

80. Ibid. 
season from 1783 to 1795 ) as the most important member of the opera buffa company. ${ }^{81}$ As is well known, he created the roles of Figaro and Guglielmo in Mozart and Da Ponte's Le nozze di Figaro and Cosi fan tutte respectively, and sang the role of Leporello when Don Giovanni was first produced in Vienna. ${ }^{82}$

Titta's three "impersonations" come in the second section of the aria (lines 7-18), following a powerful declamatory opening in D in which he delivers the first three lines in accompanied-recitative fashion (copying Sarti's music for Aeneas, as discussed above) and the next three in a rapid energetic peroration leading to a strong tonic cadence. In three successive quatrains he brags about his abilities in serving a swordsman (who used him as a practice dummy), a ballerina, and a "musico soprano." The last of these refers to his singing abilities, preparing the way for the quoted passages from "Mia speranza" (lines 19-22 and 23-24). And it must have been Benucci's acting rather than his singing in this second section of the aria that earned the audience's approval: the music for lines $7-18$, an Andante non troppo in $2 / 4$, is nothing more than a set of routine declamatory paragraphs. In the absence of musical cues, Benucci's portrayal of the three personae described must have been drawn from his own imagination and sense of dramatic style. In any event, once reinserted into the opera, "Quando saprai" remained a mainstay of the Viennese version and was included in all the commercial copies of the score that Sukowaty prepared for other cities. ${ }^{83}$

The changes to the roles of Dorina and Titta outlined above are unexpected, given that Storace and Benucci created those roles in the original Milan production and were presumably satisfied with the music written for them. In 1783, when Fra $i$ due litiganti was presented in Vienna, they were just beginning their careers in the Habsburg capital. Eager to establish themselves in the city, they changed their parts during the opera's run by substituting pieces that highlighted their acting as well as their singing abilities. As we have seen, their preferred pieces became part of the Viennese version of Fra $i$ due litiganti-the very version in which much of Europe subsequently encountered the opera.

Because Fra $i$ due litiganti was performed so widely, its history offers a valuable window into the world of opera production in the late eighteenth century: above all, how and why an opera might be altered as it moved from one opera house to another. The documented changes to the Milan version

81. See ibid., vii-xviii, for a summary of the singer's career and a list of his roles.

82. Mozart's aria "Rivolgete a lui lo sguardo," written for Benucci to sing as Guglielmo in Cosi fan tutte but cut before the first performance, is quite similar to "Quando saprai" in its many opportunities for both vocal display and comic acting.

83. The exception is H-Bn Ms. Mus. OE-4, the score prepared for Eszterháza, which as we have seen must have been completed by the beginning of July 1783 , before Benucci returned to singing "Quando saprai." As noted above, this score instead contains the soon to be abandoned "Dunque aspettate." 
of Fra $i$ due litiganti do nothing to challenge the accepted view of opera as a singers' art, one in which the preferences of the leading singers for arias best suited to them took precedence over all other considerations, resulting in the regular substitution of new or borrowed arias in each new city in which an opera was performed. However, the pattern of rigid adherence to the Viennese version of Sarti's opera creates a very different impression. As I have suggested, this pattern may have been due to the prestige of Vienna as an operatic center, and the desire of other opera houses to present works as they had been performed in that city. Alternately, the status of singers in the operatic hierarchy and the degree to which they could demand that their roles be altered may have been lower in some parts of Europe than in Vienna and Italy. Another possibility is that some opera houses (though not, presumably, those in major cities) lacked the infrastructure to produce or import substitute pieces; in particular, the scarcity of suitable composers and librettists may have been part of the reason why no substitutions were made. The exceptional case of the production in Regensburg serves to support this theory. Distinguishing among these possibilities will require further research. Studies of the performance history of other operas will be needed in order to determine whether the creation of a Viennese version of Fra $i$ due litiganti was typical of popular Italian opere buffe, and whether there were other works that also circulated in a distinct Viennese incarnation. ${ }^{84}$

Finally, it is clear from the sources that the Viennese version of the opera developed in a fluid fashion over the first few months of its performances and as a result of the interaction of the music director, the performers, and the audience. Ironically, it was this flexible and interactive process that led to the standardized, unvarying form of the opera that was transmitted to dozens of other cities over the following two decades, immortalizing a version of Fra $i$ due litiganti substantially different from the one that Sarti originally created. ${ }^{85}$

84. For one such study, see Schraffl and Niubo, "Paisiello's La frascatana." That opera's history has certain parallels to that of Fra $i$ due litiganti: it came to Vienna from Italy (specifically from Venice) during 1775-76, also in the first season of a newly formed Italian opera company, and like Sarti's opera it was hugely popular, with forty performances in one season.

85. Portions of this article were presented at the international conference on Giuseppe Sarti, Berlin, July 2104; the annual meeting of the American Musicological Society, Milwaukee, November 2014; and the biennial meeting of the Mozart Society of America, Tufts University, September 2015. I am grateful to Jennifer Noakes (Trinity College, '01), Emma Platoff, and Suzanne Platoff for research help. 


\section{Works Cited}

\section{Sources for Fra $i$ due litiganti}

\section{Librettos in Italian}

All under the title Fra $i$ due litiganti il terzo gode except as noted

Milan 1782 (Sartori 10899)

Turin 1782 (Sartori 10900)

Venice 1782, as I pretendenti delusi (Sartori 19051)

Hanover 1783, as I pretendenti delusi (C. W. H. Pockwitz)

Prague 1783 (Sartori 10901)

Vienna 1783 (Sartori 10902)

Vienna 1783, as Frai [sic] due litiganti il terzo gode (Giuseppe Nob. de Kurtzbeck)

Barcelona 1784, as I due pretendenti delusi (Sartori 8540)

Dresden 1784 (Sartori 10903)

Florence 1784, as Tra due litiganti il terzo gode (Sartori 23362)

London 1784, as I rivali delusi (Sartori 20021)

Naples 1784, as Le nozze di Dorina (Sartori 16726)

Treviso 1784 (Sartori 10904)

Trieste 1784, as Fra $i$ due litiganti alcun non gode (Sartori 10897)

Udine 1784, as Fra due litiganti il terzo gode (Sartori 10905)

Ferrara 1785 (Sartori 10906)

Gorizia 1785, as Fra $i$ due litiganti alcun non gode (Sartori 10898)

Siena 1785, as Fra due litiganti il terzo gode (Sartori 10907)

Stuttgart 1785, as Fra due litiganti il terzo gode (Sartori 10908)

Brescia 1786, as Fra li due litiganti il terzo gode (Sartori 10910)

Corfu 1786 (Sartori 10911)

Regensburg 1786 (Sartori 10912)

Reggio 1786, as I pretendenti delusi (Sartori 19053)

Rome 1786, as Tra due litiganti il terzo gode (Sartori 23364)

Vicenza 1786, as Fra li due litiganti il terzo gode (Sartori 10913)

Berlin 1787 (Sartori 10914)

Crema 1787 (Sartori 10915)

Novara 1787 (Vercelli: Giuseppe Panialis)

Paris 1789, as Le nozze di Dorina (Sartori 16727)

Padua 1792, as I due litiganti (Sartori 8532)

Lisbon 1793 (Sartori 10916)

London 1793, as Le nozze di Dorina (Sartori 16729)

Udine 1793 (Sartori 10917)

Milan 1795 (Sartori 10919)

Verona 1795, as Fra due litiganti il terzo gode (Sartori 10920)

Turin 1796, as Le nozze di Dorina (Sartori 16730)

Zara [Zadar] 1796 (Sartori 10921)

Rovigo 1798 (Sartori 10922) 


\section{Librettos in German or French}

Bonn 1784, as Unter zwei Streitenden zieht ein Dritter den Nussen

Cologne 1786, as Im Trüben ist gut fischen, trans. Johann André

Paris and Brussels 1786, as Hélène et Francisque, trans. Pierre-Ulric Dubuisson (Brussels: F. Hayez)

Salzburg 1787, as Unter zwei Streitenden zieht ein Dritter den Nussen, [trans. Ludwig Zehnmark]

Vienna 1787, as Im Trüben ist gut fischen, trans. Johann André (Logen-Meister)

Cologne 1788, as Im Trüben ist gut fischen, trans. Johann André (2nd ed., Joh. Godch. Langen)

Hamburg 1791, as Im Trüben ist gut fischen (Johann Matthias Michaelson)

Hamburg 1795, as Hélène et Francisque (P. F. Fauche)

Amsterdam n.d., as Im Trüben ist gut fischen, trans. Johann André (J. E. Röder)

Augsburg n.d., as Im Trüben ist gut fischen (Simon Kapser)

\section{Scores}

All under the title Fra $i$ due litiganti il terzo gode except as noted

*signed Sukowaty score

** score identified as being from Sukowaty's shop on the basis of musical handwriting

Berlin, Staatsbibliothek zu Berlin-Preußischer Kulturbesitz, Musikabteilung (D-B), Mus. Ms. 19493, as Im Trüben ist gut fischen**; Mus. Ms. 19493-1, as Von zwey Streitenden erbält er dritte den Sieg

Bologna, Museo internazionale e biblioteca della musica (I-Bc), K.K. 75

Bolzano, Biblioteca privata dei Conti Toggenburg (I-BZtoggenburg), D/II, $5^{\text {** }}$

Budapest, Országos Széchényi Könyvtár (H-Bn), Ms. Mus. OE-4*

Copenhagen, Det Kongelige Bibliotek på Slotsholmen-Den Sorte Diamant (DK$\mathrm{Kk}), \mathrm{mu} 7402.0802^{*}$; mu7408.2631, as I oproert Van er godt at fiske

Donaueschingen, Fürstlich Fürstenbergische Hofbibliothek (D-DO), Mus. Ms. $1723 a-c^{* *}$

Dresden, Sächsische Landesbibliothek-Staats- und Universitätsbibliothek (SLUB) (D-Dl), Mus. 3273-F-503; Mus. 3273-F-6

Florence, Conservatorio di Musica Luigi Cherubini, Biblioteca (I-Fc), F 10035 F.P. T. 470; F 10035 F.P.T. 733 (piano-vocal score)

Forlì, Biblioteca comunale Aurelio Saffi (I-FOc), I/86

Frankfurt am Main, Universitätsbibliothek Johann Christian Senckenberg, Abteilung Musik und Theater (D-F), Mus. Hs. Opern 505, as Wer das Glück hat, führt die Braut heim

Frederiksberg, Musikmuseet (DK-Km), R 428

Harburg (Schwaben), Öttingen-Wallersteinische Bibliothek (D-HR), III 4 1/2 $\left.4\right|_{0}$ $79^{* *}$

Munich, Bayerische Staatsbibliothek (D-Mbs), St. th. 107-1

Münster, Santini-Bibliothek (D-MÜs), Hs 3831 1.II

Paris, Bibliothèque nationale de France, Département de la Musique (F-Pn), 10987; VM4-538**; VM4-539*

Paris: Sieber, ca. 1789, as Les noces de Dorine, ou Hélène et Francisque

Parma, Sezione musicale della Biblioteca Palatina (I-PAc), 17679-80 M-V-13-14 
Regensburg, Fürst Thurn und Taxis Hofbibliothek und Zentralbibliothek (D-Rtt), Sarti 5 , as I pretendenti delusi* *

Rome, Biblioteca privata dei Principi Massimo (I-Rmassimo)

Rudolstadt, Landesarchiv Thüringen-Staatsarchiv Rudolstadt (D-RUl), SH 437

Schwerin, Landesbibliothek Mecklenburg-Vorpommern Günther Uecker, Musikaliensammlung (D-SWl), Mus. 4763, as I prettendenti delusi

St. Petersburg, Central'naja muzykal'naja biblioteka Mariinskogo teatra (RUSSPtob), 467 (partial autograph)

Stuttgart, Württembergische Landesbibliothek (D-Sl), HB XVII $572 \mathrm{a}-\mathrm{d}$, as Im Trüben ist gut fischen**

Turin, Archivio dell'Accademia filarmonica (I-Tf), 1. II. 18-19; 1. V. 25-26

Vienna, Gesellschaft der Musikfreunde (A-Wgm), IV 71115

Vienna, Österreichische Nationalbibliothek, Musiksammlung (A-Wn), KT 357; Mus. Hs. 17888**

Weimar, Hochschule für Musik Franz Liszt, Hochschularchiv (D-WRha), DNT 7, as Im Trüben ist gut fischen

Wolfenbüttel, Niedersächsiches Landesarchiv—Standort Wolfenbüttel (D-Wa), 46 Alt 5-6 (Sarti 3), as I pretendenti delusi

Zurich, Zentralbibliothek, Musikabteilung (CH-Zz), AMG XIV, 781 (Ms. 701)

\section{Secondary Literature and Editions}

Albrecht-Hohmeier, Martin, and Christine Siegert. "Eine codierte Opernedition als Angebot für Wissenschaft, Lehre und Musikpraxis: überlegungen am Beispiel von Giuseppe Sarti (1729-1802)." In Vom Nutzen der Editionen: Zur Bedeutung moderner Editorik für die Erforschung von Literatur-und Kulturgeschichte, edited by Thomas Bein, 1-17. Berlin: De Gruyter, 2015.

Bartha, Dénes, and László Somfai. Haydn als Opernkapellmeister: Die HaydnDokumente der Esterházy-Opernsammlung. Budapest: Ungarischen Akademie der Wissenschaften, 1960.

Brown, Bruce Alan. W. A. Mozart: Così fan tutte. New York: Cambridge University Press, 1995.

Brown, Jennifer Williams. "On the Road with the 'Suitcase Aria': The Transmission of Borrowed Arias in Late Seventeenth-Century Italian Opera Revivals.” Journal of Musicological Research 15, no. 1 (1995): 3-23.

Butler, Margaret R. "From Guadagni's Suitcase: A Primo Uomo's Signature Aria and Its Transformation." Cambridge Opera Journal 27, no. 3 (November 2015): 239-62.

Edge, Dexter. "Mozart's Fee for Cosi fan tutte." Journal of the Royal Musical Association 116, no. 2 (1991): 211-35.

—_. "Mozart's Viennese Copyists." PhD diss., University of Southern California, 2001.

Emerson, Isabelle. Five Centuries of Women Singers. Westport, CT: Praeger, 2005.

- "Migrating Mozart, or Life as a Substitute Aria in the Eighteenth Century." Min-Ad: Israel Studies in Musicology Online 5, no. 2 (2006): 40-56. https://biu .ac.il/hu/mu/min-ad/.

The Favorite Songs in the Opera "I rivali delusi." London: J. Preston, 1785 (RISM ID 990057415). 
Freeman, Robert. "Farinello and His Repertory." Studies in Renaissance and Baroque Music in Honor of Arthur Mendel, edited by Robert L. Marshall, 301-30. Kassel: Bärenreiter, 1974.

Genesi, Mario Giuseppe. Una primadonna tardosettecentesca: Brigida Giorgi Banti (1755-1806). Monticelli d'Ongina: Pro Loco, 1991.

Gidwitz, Patricia Lewy. “'Ich bin die erste Sängerin': Vocal Profiles of Two Mozart Sopranos.” Early Music 19, no. 4 (November 1991): 565-79.

— "Vocal Profiles of Four Mozart Sopranos." PhD diss., University of California, Berkeley, 1991.

Glatthorn, Austin. "In the Name of the Emperor: Representational Theater and the Princes of Thurn und Taxis." Journal of Musicology 35, no. 1 (Winter 2018): 1-41.

Hunter, Mary. The Culture of Opera Buffa in Mozart's Vienna: A Poetics of Entertainment. Princeton: Princeton University Press, 1999.

Link, Dorothea. Arias for Francesco Benucci, Mozart's First Figaro and Guglielmo. Recent Researches in Music of the Classical Era 72. Middleton, WI: A-R Editions, 2004.

- Arias for Nancy Storace, Mozart's First Susanna. Recent Researches in Music of the Classical Era 66. Middleton, WI: A-R Editions, 2002.

- The National Court Theatre in Mozart's Vienna: Sources and Documents, 1783-1792. Oxford: Clarendon Press, 1998.

Loewenberg, Alfred. Annals of Opera, 1597-1940. With an introduction by Edward J. Dent. 2nd ed. Geneva: Societas Bibliographica, 1955.

Meixner, Christoph. Musiktheater in Regensburg im Zeitalter des Immerwährenden Reichstages. Sinzig: Studio, 2008.

Michtner, Otto. Das alte Burgtheater als Opernbühne: Von der Einführung des deutschen Singspiels (1778) bis zum Tod Kaiser Leopolds (1792). Vienna: Böhlau, 1970.

Nahon, Marino. "Le origini del rondò vocale a due tempi: tempo musicale e tempo scenico nell'aria seria tardosettecentesca." Musica e storia 13, no. 1 (June 2005): $25-80$.

Pfeiffer, Roland. Die Opere buffe von Giuseppe Sarti (1729-1802). Kassel: Gustav Bosse, 2007.

Platoff, John. "The Buffa Aria in Mozart's Vienna." Cambridge Opera Journal 2, no. 2 (July 1990): 99-120.

— . "How Original Was Mozart? Evidence from Opera Buffa." Early Music 20, no. 1 (February 1992): 105-17.

_. "A Mozart Duet in a Sarti Opera: 'Là ci darem la mano' in Udine, 1793." Eighteenth-Century Music 14, no. 1 (March 2017): 117-22.

Poriss, Hilary. Changing the Score: Arias, Prima Donnas, and the Authority of Performance. Oxford: Oxford University Press, 2009.

Rice, John A. Antonio Salieri and Viennese Opera. Chicago: University of Chicago Press, 1998.

—_. "Bearbeitungen italienischer Opern für Wien 1765-1800." In Bearbeitungspraxis in der Oper des späten 18. Jahrhunderts, edited by Ulrich Konrad, Armin Raab, and Christine Siegert, 81-101. Tutzing: Hans Schneider, 2007.

- "A Libretto Collection from the Circle of Vincenzo Calvesi, Mozart's Ferrando." In Music Observed: Studies in Memory of William C. Holmes, edited by Colleen Reardon and Susan Parisi, 429-46. Warren, MI: Harmonie Park Press, 2004 . 
"Sense, Sensibility, and Opera Seria: An Epistolary Debate." Studi musicali 15, no. 1 (1986): 101-38.

Sartori, Claudio. I libretti italiani a stampa dalle origini al 1800: Catalogo analitico con 16 indici. 6 vols. in 7. Cuneo: Bertola e Locatelli, 1990-94.

Schraffl, Ingrid, and Marc Niubo. "Paisiello's La frascatana: Dramaturgical Transformations on Its Journey through Central Europe." Musicologica austriaca, January 29, 2017. http://www.musau.org//parts/neue-article-page/view/30.

Siegert, Christine. "Rezeption durch Modifikation: Verbreitungswege italienischer Opern des späten 18. Jahrhunderts im deutschsprachigen Raum.” In Oper im Aufbruch: Gattungskonzepte des deutschsprachigen Musiktheaters um 1800, edited by Marcus Chr. Lippe, 111-31. Kassel: Gustav Bosse, 2007.

Verti, Roberto, ed. Un almanacco drammatico: L'indice de' teatrali spettacoli, 17641823. Facsimile reprint, Pesaro: Fondazione G. Rossini, 1996.

Waisman, Leonardo J., and Angela Romagnoli. Vicente Martín y Soler: Un músico español en el clasicismo europeo. Madrid: Instituto Complutense de Ciencias Musicales, 2007.

Woodfield, Ian. The Vienna "Don Giovanni."Woodbridge, UK: Boydell Press, 2010.

\section{Abstract}

Giuseppe Sarti's opera Fra $i$ due litiganti, premiered in Milan in 1782, was the first great success of the reconstituted Italian opera company in Vienna in 1783. The opera sustained its enormous Viennese popularity for years, while also being performed in over one hundred other European cities by 1800. Mozart's quotation of the work in Don Giovanni testifies to its continuing appeal. But the version of the opera that was so successful in many parts of Europe differed substantially from the Milanese original. The surviving manuscript scores and printed librettos reveal that a standardized Viennese version of Fra $i$ due litiganti, in which more than a third of the original arias were replaced, became the basis for productions across much of Europe. This unexpected standardization may reflect the prestige of Vienna and its role as a distribution point for opera scores, especially since many of the manuscripts were produced by Wenzel Sukowaty, the copyist for the Viennese court theaters. The Viennese changes surprisingly include arias for Nancy Storace and Francesco Benucci-later Mozart's Susanna and Figarowho had themselves created the same roles in Milan. (Normally arias would be substituted to suit the preferences of new singers.) These alterations not only changed the profiles of the characters, but allowed Storace and Benucci to define themselves for the Viennese public, establishing the musical and dramatic personae that quickly made them the beloved favorites of Viennese audiences.

Keywords: Nancy Storace, Francesco Benucci, Wenzel Sukowaty, opera transmission, substitute arias 


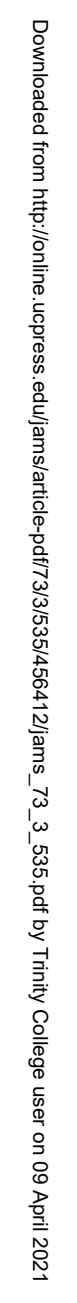

